\title{
Role of aquifer media in determining the fate of polycyclic aromatic hydrocarbons in the natural water and sediments along the lower Ganges river basin
}

Srimanti Duttagupta, Abhijit Mukherjee, Joyanto Routh, Laxmi Gayatri Devi, Animesh Bhattacharya and Jayanta Bhattacharya

The self-archived postprint version of this journal article is available at Linköping University Institutional Repository (DiVA):

http://urn.kb.se/resolve?urn=urn:nbn:se:liu:diva-162939

N.B.: When citing this work, cite the original publication.

This is an electronic version of an article published in:

Duttagupta, S., Mukherjee, A., Routh, J., Devi, L. G., Bhattacharya, A., Bhattacharya, J., (2020), Role of aquifer media in determining the fate of polycyclic aromatic hydrocarbons in the natural water and sediments along the lower Ganges river basin, Journal of Environmental Science and Health. Part A. https://doi.org/10.1080/10934529.2019.1696617

Original publication available at:

https://doi.org/10.1080/10934529.2019.1696617

Copyright: Taylor \& Francis (STM, Behavioural Science and Public Health Titles) http://www.tandf.co.uk/journals/default.asp 


\title{
Role of aquifer media in determining the fate of polycyclic aromatic hydrocarbons in the natural water and sediments along the lower Ganges river basin
}

Srimanti Duttagupta ${ }^{1 *}$, Abhijit Mukherjee ${ }^{1,2}$, Joyanto Routh ${ }^{3}$, Laxmi Gayatri Devi ${ }^{3}$, Animesh Bhattacharya $^{1,4}$, Jayanta Bhattacharya ${ }^{1,5}$

1. School of Environmental Science and Engineering, Indian Institute of Technology Kharagpur, Kharagpur 721302, India

2. Department of Geology and Geophysics, Indian Institute of Technology Kharagpur, Kharagpur 721302, India

3. Department of Water and Environmental Studies, TEMA, Linköping University, Linköping 58183, Sweden

4. Public Health Engineering Department, Government of West Bengal, Kolkata 700001, India

5. Department of Mining Engineering, Indian Institute of Technology Kharagpur, Kharagpur 721302, India

\begin{abstract}
Groundwater-sourced drinking water quality in South Asia, specifically India, is extremely stressed, mostly from the presence of many pervasive and geogenic pollutants. The presence and behavior of anthropogenic pollutants like polycyclic aromatic hydrocarbons (PAHs) are poorly investigated on a regional or basin-wide scale. The present study provides one of the first documentation of the presence and behavior of PAH in the aquifer sediments in the Ganges river basin. Lower and medium molecular weight PAHs e.g., naphthalene, phenanthrene, and fluoranthene were detected in 79,36 and $13 \%$ of samples $(n=25)$. The PAH level in groundwater was approximately five times lower than river water. The sorption behaviour of PAHs were studied in experiments in presence/absence of organic carbon and by simulating advective transport of low to medium molecular weight PAHs e.g., naphthalene, phenanthrene and fluoranthene in aquifer sediments collected from agricultural, peri-urban and
\end{abstract}


urban areas. Naphthalene and phenanthrene adsorbed on quartz and kaolinite, but not on clay minerals like kaolinite. Fluoranthene adsorbed more favourably on kaolinite. Numerical modeling of the advective transport of PAHs in aquifers suggest up to 25 times faster movement of pollutants from irrigation-induced pumping, indicating the strong control of hydraulics on the spatial distribution of PAHs in sub-surface.

*Corresponding Author: Srimanti Duttagupta, School of Environmental Science and Engineering, Indian Institute of Technology Kharagpur, Kharagpur 721302, West Bengal, India; Phone: +91-9903025535; Email: srimanti.duttagupta@gmail.com

\section{Keywords}

Land use; Sediment; Groundwater; Ganges River; Contamination; Transport; Extraction; Pyrogenic; Petrogenic; Pumping 


\section{Introduction}

The mobility, persistence, and extensive consumption of polycyclic aromatic hydrocarbons (PAHs) have resulted in widespread drinking water contamination $^{[1]}$. Accumulation of contaminants like PAHs in aquifers and the use of contaminated groundwater for irrigation further detiorerates the situation, and raises concern about their exposure to the public $^{[2]}$. The introduction of such toxic organic chemicals in aquifer sediments and groundwater has troubled the natural catabolic processes and threaten human health ${ }^{[3]}$. For example, the study conducted in the Vhembe district, South Africa showed that prevalence of higher molecular weight PAHs are elevated in industrial effluents, which are eventually transported into surface and groundwater bodies, and pose a challenge to human health issues [4]. The sources of these compounds are primarily anthropogenic. Vehicles release wideranging organic and inorganic compounds from incomplete combustion of fossil fuels, leakage, and operation of catalytic converters. In particular, PAHs present in petroleum hydrocarbons and wood preservatives like creosote are toxic to the ecosystem because of their lipophilic character and detrimental effects toresulting in mutagenic and carcinogenic changes $[5,6]$. PAHs adsorb to sediments because of their high hydrophobicity and solid-water distribution ratios ${ }^{[7,8]}$. In addition, the sorption of PAHs is influenced by its degradation and transport in aquatic environments ${ }^{[9]}$. This phenomenon is related to the retention capacity of PAHs in sediments which varies between the compounds.

PAHs have been intensely investigated over the last few decades due to their widespread occurrence and persistence in nature ${ }^{[10-13,8]}$. PAHs reported in different locations from the world including the present study area are given in Table 1.

In India, several studies have investigated the spatial distribution of PAHs. For example Mitra et al ${ }^{[14]}$ studied the surface sediments $(0-5 \mathrm{~cm})$ in the Hooghly River estuary in the 
Western Bengal basin. Anthropogenic activities resulted in the introduction of different point and non-point source PAHs in drinking water in the area. While different sources of PAHs and its distribution in natural waters and sediments have been investigated, PAH sorption behavior in these environments are rarely explored.

The Ganges River basin is a densely populated region with an areal extent of about $21,000 \mathrm{~km}^{2}{ }^{[15,16]}$. Approximately $2 \%$ of the world's population resides in this region. Groundwater in major parts of the Ganges River basin has been studied for inorganic geogenic pollutants such as arsenic and fluoride. Although the presence of various anthropogenicsourced pollutants has been indicated in the Ganges river basin, there is a dearth of detailed or site-specific information. In particular, the prevalence and fate of PAHs in the arseniccontaminated aquifers of the Western Bengal basin is largely unknown.

The primary objectives of this study are to 1) provide a detailed understanding of spatial distribution of PAHs in groundwater, and 2) examine sorption phenomenon of commonly occurring PAHs on surface sediments from the Western Bengal basin. Specifically, the distribution and quantification of PAHs derived from industrial sources and vehicular emissions were examined in this study. The influence of land-use on PAH distribution arising from pumping of groundwater that is mainly used for agriculture was determined using advective transport modeling. This study documents for the first time detailed information on the spatial distribution of PAHs on a basin-wide scale and impacts of groundwater pumping to sustain the high agricultural demands. The information generated in this study will be useful for land management and land-use practices to safeguard the groundwater and surface water resources in the Ganges River basin. 


\section{Materials and Methodology}

\section{Sample collection}

Approximately, $1 \mathrm{~L}$ groundwater $(\mathrm{n}=235)$ and river water $(\mathrm{n}=32)$ samples were collected for analyses of PAHs during 2015 for two seasons in pre-cleaned high-density polyethylene bottles (HDPE) following EPA Method 680 (Table 1S - 3S). The sediment samples were collected from three different depths $(0-30 \mathrm{~cm})$ in 25 locations across the Western Bengal basin. Few sites $(n=14)$ were close to national highways and they were situated in peri-urban and urban areas. Some of the samples $(n=11)$ were collected adjacent to agricultural lands (Fig. 1).. Sediments were collected in a sealed and sterilized bottle. The samples were homogenized and passed through a $2 \mathrm{~mm}$ sieve and oven-dried and stored in airtight containers.

\section{Extraction of PAHs from water and sediment samples}

$16 \mathrm{PAHs}\left(\sum \mathrm{PAH}_{16}\right)$ in both river water and groundwater samples were extracted from $1 \mathrm{~L}$ of water sample, by passing through methanol and de-ionized water pre-conditioned $6 \mathrm{~mL} \mathrm{C18-}$ solid-phase cartridges (Thermo Scientific). Subsequently, the $\sum \mathrm{PAH}_{16}$ in the aforesaid air-dried C18 cartridge was eluted using $6 \mathrm{~mL}$ of methanol. The eluent was further concentrated using a rotary evaporator with nitrogen purging. The residue was dissolved in $3 \mathrm{~mL}$ of $\mathrm{n}$-hexane and dichloromethane (50:50 volume ratio) and taken to near dryness under $\mathrm{N}$ flow. The extractwas redissolved in $300 \mu \mathrm{L}$ of hexane and refrigerated until further analysis.

Dried and homogenized $5 \mathrm{~g}$ of sediment was extracted with a mixture of dichloromethane and n-hexane $(9: 1 \mathrm{v} / \mathrm{v})$. A Dionex ${ }^{\circledR}$ Accelerated Solvent Extractor 300 was used by programming it for three extraction cycles at $1000 \mathrm{psi}$ and $100^{\circ} \mathrm{C}^{[19,20]}$ followed by solid-phase extraction (SPE) using $6 \mathrm{~mL}$ C18 SPE glass cartridges, pre-rinsed with methanol and dichloromethane ${ }^{[21]}$. 


\section{PAH analyses in water and sediment samples}

The PAHs and their alkylated derivatives in the sediment and water samples were analyzed by using a gas chromatograph-mass spectrometer (Agilent ${ }^{\circledR} 7890$ A). Sample injection was done in split-less mode into an ion trap Agilent 7890A gas chromatograph mass spectrometer, equipped with a DB5-MS column $(30 \mathrm{~m} \times 0.25 \mathrm{~mm}$ inner diameter $\times 0.25 \mu \mathrm{m}$ film). GC oven temperature was varied from 70 to $200^{\circ} \mathrm{C}$ at $20{ }^{\circ} \mathrm{C} / \mathrm{min}$. The increase in temperature was up to $310^{\circ} \mathrm{C}$ (with a hold time of $15 \mathrm{~min}$ ), and up to a final temperature of $315^{\circ} \mathrm{C}$ (with a hold time of $4 \mathrm{~min}$ ) at $5^{\circ} \mathrm{C} / \mathrm{min}$. Quality control was done by analyzing solvent blanks and routine blanks, along with a five-point calibration curve using DCM and hexane based standards (NIST 16 PAH mix, $1000 \mu \mathrm{g} / \mathrm{L}$ ) to quantify 16 PAHs ( $\Sigma$ PAHs 16 ). PAH identification was done based on their retention time and mass spectra. The limits of detection (LOD) for PAHs were in $\mu \mathrm{g} / \mathrm{kg}$ concentrations and accuracy and precision, using triplicates were better than $\pm 5 \%$. From a batch of 25 sediment samples, five samples were selected for sorption studies based on the detailed mineral and elemental characterization.

Mineral characterization was carried using PANalytical X'pert Powder. Samples were packed in the flat sample stage holder, and the XRD pattern was obtained on the instrument using $\mathrm{Cu} \mathrm{K} \alpha$ radiation equipped with a diffracted - beam monochromator in the range of 5-75 (2Ө) at the rate $0.00013^{\circ}$. Results were evaluated by Highscore Plus to detect the most abundant peaks and relative quantification. Each sample was analyzed three times to improve the signalto-noise ratio ${ }^{[22]}$.

\section{Sorption experiments}

Sorption phenomenon of selected PAHs was studied on natural sediments and laboratorygrade synthetic minerals using a batch equilibrium technique based on OECD Guideline 106 [23]. Glass vials with Teflon cap were used for the experiment. The solid to liquid ratio in the 
experiment was 0.4 for laboratory kaolinite and 1.0 for quartz since it has a low surface area. Based on the mineral characteristics, quartz and kaolinite the dominant minerals in these sediment were considered for the sorption study. About $5 \mathrm{~g}$ of homogenized sediments were equilibrated with $4 \mathrm{~mL}$ of ultrapure water for 24 hours. $1 \mathrm{~mL}$ of each PAH solution was added to both and glass tubes were placed on a horizontal shaker. The suspension was centrifuged at $4000 \mathrm{rpm}$ for $30 \mathrm{~min}$ and the supernatant was set aside for further analysis. Each sample was prepared in triplicate for the sorption experiment. Five different concentrations have been considered for the isotherm study. Two PAH solutions were prepared with concentration ranging from 0.25 to $1 \mathrm{mg} / \mathrm{L}$. The experiment was conducted for 30 hours and PAH concentrations in sediments was analysed at 3-hr intervals. A similar procedure was followed for the laboratory-grade kaolinite and quartz powder. Langmuir and Freundlich isotherm model was used to demonstrate monolayer adsorption of PAHs onto natural sediments as well as on laboratory-grade kaolinite and quartz powders.

The results for adsorption of PAHs were analysed using the Langmuir and Freundlich models. The Langmuir isotherm has been used by previous workers for studying sorption of different compounds ${ }^{[24]}$. The model assumes a uniform adsorption energy on the surface and no transmigration of adsorbate on the plane of the surface. The Langmuir adsorption isotherm is mathematically represented as equation 1 :

$$
\frac{\mathbf{1}}{q_{e}}=\frac{\frac{\mathbf{1}}{q_{\max }+1}}{b} q_{\max \mathbf{C}_{e}}
$$

where, $\mathrm{q}_{\mathrm{e}}$ is the amount adsorbed $(\mathrm{mg} / \mathrm{g}), \mathrm{C}_{\mathrm{e}}$ is the equilibrium concentration of the adsorbate $(\mathrm{mg} / \mathrm{L})$ and $\mathrm{Q}_{\max }$ and $\mathrm{b}$ are the Langmuir constants related to maximum adsorption capacity and adsorption energy, respectively. 
The adsorption data for PAHs were also analysed using the Freundlich model. The Freundlich adsorption isotherm is mathematically represented by Equation 2:

$$
\log q_{e}=\log K_{f}+\frac{1}{n} \log C_{e}
$$

where $\mathrm{q}_{\mathrm{e}}$ is the amount adsorbed $(\mathrm{mg} / \mathrm{g}), \mathrm{C}_{\mathrm{e}}$ is the equilibrium concentration of the adsorbate $(\mathrm{mg} / \mathrm{L})$ and $\mathrm{K}_{\mathrm{f}}$ and $\mathrm{n}$ are Freundlich constants related to adsorption capacity and adsorption intensity, respectively ${ }^{[25]}$.

\section{Quality assurance and quality control}

The quality assurance and quality control (comprised laboratory quality control procedures including analysis of the reference material (laboratory grade sand and kaolinite), field blanks and laboratory blanks, and spiked $(1 \mu \mathrm{g} / \mathrm{L})$ PAHs (naphthalene, phenanthrene, and fluoranthene) added to the samples. Laboratory-grade kaolinite and quartz were considered for laboratory blanks. Deuterated-perylene and chrysene were injected with a concentration of 0.5 and $1 \mu \mathrm{g} / \mathrm{L}$ respectively (Table $4 \mathrm{~S}$ and $5 \mathrm{~S}$ ). The recovery percentages were $79 \%$ for the water samples and $74 \%$ for the sediment samples. Laboratory blanks were also used for extraction and PAH analyses were conducted following the similar procedure.

\section{Statistical analysis}

All values were specified as a mean of three determinations. The Student's t-test established the comparison between the mean of total PAH concentrations; $p<0.05$ was considered as statistically significant. The t-statistics value was analysed from the coefficient ratio of an independent variable and standard error. A $t$-value of 0 indicates that the sample supports the null hypothesis. As the difference between the sample data and the null hypothesis increases, the absolute magnitude of $t$-value increases. The $p$-value (probability value) was calculated using the probability density function which describes the likelihood of a $t$-value and whether 
it is statistically significant ${ }^{[26]}$. Spearman correlation coefficient ${ }^{[27]}$ was used to observe the relationship between PAHs in 25 sediment samples. Multivariate statistics using hierarchical cluster analyses (HCA) were done on the original data set (without any weighting or standardization) ${ }^{[28]}$. The HCA dendrogram was constructed by Ward's method with squared Euclidean distance ${ }^{[29]}$. HCA was used to investigate relationships between the locations. HCA was also analyzed by E-views statistical software (v. 9.5).

\section{Advective transport}

High-resolution calibrated 3D-groundwater flow modeling in seasonal scale was used to replicate the groundwater flow path through anisotropic and heterogeneous aquifers in the study area following Mukherjee et al. ${ }^{[16]}$ in a finite difference grid using MODFLOW codes ${ }^{[29]}$ in dynamic-equilibrium mode. The entire model domain of the $21,000 \mathrm{~km}^{2}$ lower Ganges basin was numerical gridded, with a horizontal resolution of $1000 \mathrm{~m}$ (x) and $1000 \mathrm{~m}(\mathrm{y})$, with 22 vertical layers from surface to 300 below ground level, and a resolution of $15 \mathrm{~m}(\mathrm{z})$. Details of the regional hydrostratigraphy were screened from Mukherjee et al. ${ }^{[16]}$ and information from 141 lithologs. Hypothetical, conservative PAH particles were simulated using MODPATH ${ }^{[30]}$ for advective transport to target wells at $50 \mathrm{~m}$ depth, from time $t_{l}$ (infiltration time at the source) to $t_{n}$ (transport time to the targeted drinking water well) that were nested on telescopically-refined grids $(100 \mathrm{~m} \times 100 \mathrm{~m} \times 10 \mathrm{~m}, 31$ layers $)$ of the aforesaid groundwater flow path model and calibrated boundary conditions and hydraulic properties. The hypothetical source-particles were designed to be present horizontally between $10 \mathrm{~m}$ to $1500 \mathrm{~m}$ and at depths of $50 \mathrm{~m}$ from topographic elevation. For the particle transport simulations, base-line conditions of no irrigational pumping and present-day pumping conditions were included. 


\section{Results and discussion}

\section{Distribution of PAHs}

$\sum$ PAHs 16 were detected in the groundwater with a mean concentration of 3.45 and 5.31 $\mu \mathrm{g} / \mathrm{L}$ in river water samples during 2015. The $\sum \mathrm{PAHs}_{16}$ concentrations in groundwater and river water across the study area varied from 0.01 to $8.01 \mu \mathrm{g} / \mathrm{L}$ and 0.02 to $6.22 \mu \mathrm{g} / \mathrm{L}$, respectively (Fig. 2, Table 3S). In order to detect the extent of low, medium and high molecular weight PAHs in different groundwater and river water samples, PAH compounds were divided into three groups: $2+3$ rings or low molecular weight PAHs (LMs), 4-rings or medium molecular weight PAHs (MMs) and $5+6$ rings or high molecular weight PAHs (HMs). The percentage of LMs to total PAHs was higher than that of MMs and HMs in groundwater samples, indicating that LMs were predominant in water samples. Naphthalene and phenanthrene were the dominant LMs. MMs were detected but at low levels HMs such as sixring PAHs were detected in trace amount in both groundwater and river water samples. The total and individual concentrations of PAHs detected in river and groundwater samples $(\mu \mathrm{g} / \mathrm{L})$ from the Western Bengal basin are listed in appendix A. Among 235 groundwater samples, naphthalene was predominant in $79 \%$ samples followed by fluoranthene ( $26 \%$ of samples) and phenanthrene ( $3 \%$ of samples). Groundwater indicated thatnaphthalene was the dominant PAH with a maximum concentration of $8.25 \mu \mathrm{g} / \mathrm{L}$. Presence of alkylated PAHs such as 2-methyl naphthalene (55\%), 1-methyl naphthalene (22\%), and 1, 3-dimethyl naphthalene (31\%) was also detected in the study area. The PAH levels in groundwater were approximately five times lower than river water (Fig. 2). Low molecular weight PAHs (2-3 rings) were predominant in surface water samples in river water and, on average, accounted for $75 \%$ of the total PAHs. Naphthalene was the most common PAH found in river water samples ( $84 \%$ of the samples) followed by phenanthrene ( $29 \%$ of the samples) among 32 river water samples. Three-ring PAHs were predominant among individual PAHs, and six-ring PAHs were not detected. It was 
noted that naphthalene was the dominant individual PAH. The highest concentration of naphthalene exceeded $>3 \mu \mathrm{g} / \mathrm{L}$ at 5 locations in river water samples.

While the predominant PAH was naphthalene its alkylated derivatives including 1, 3dimethyl naphthalene, 2, 6-dimethyl naphthalene, 1-methyl naphthalene, and 2-methyl naphthalene and fluoranthene were also found in river water. The abundance of alkylated PAHs in river water samples were as follows: 2-methyl naphthalene (12\%), 2, 6-dimethyl naphthalene (10\%), 1, 3-dimethyl naphthalene (4\%), 1-methyl naphthalene (2\%) and fluoranthene (2\%) in. Anthracene and chrysene were detected in trace amounts in groundwater and river water. The spatial distribution of four predominant PAHs is shown in Figure 3.

According to Koh et al. and Khairy et al. ${ }^{[32,33]}$, it has been observed that medium molecular weight (MM) PAHs are predominant in sediments whereas, low molecular weight PAHs (LMs) are dominant in water samples. LMs such as naphthalene and phenanthrene are more soluble and also degradable, whereas HMs such as pyrene and benzo(a)anthracene are comparatively more stable ${ }^{[33,34]}$. Overall, HMs are hydrophobic and more resistant to degradation (Bakhtiari et al., 2009) . As a result, HMs readily adsorb to sedimentss and eventually settle down and accumulate in bottom sediments.

PAH concentrations in sediment from different depth intervals $(0-10 \mathrm{~cm}, 10-20 \mathrm{~cm}$, and 20-30 cm) indicated distinct differences (Fig. 4, Table 6S). The sediment samples collected from $0-10 \mathrm{~cm}$ showed the maximum PAH concentration $(2.22 \mu \mathrm{g} / \mathrm{kg}$ dry weight $)$. Sediment samples collected from $10-20 \mathrm{~cm}$ and $20-30 \mathrm{~cm}$ depth intervals indicated a total PAH concentration of 2.02 and $1.95 \mu \mathrm{g} / \mathrm{kg}$, respectively. Naphthalene was the most common PAH in these sediments. The sediment sample collected from $0-10 \mathrm{~cm}$ consisted of mostly naphthalene (79\%), phenanthrene (36\%), fluoranthene (13\%), and benzo (a) pyrene (9\%). However, sediments collected from $10-20 \mathrm{~cm}$ and 20-30 $\mathrm{cm}$ depth indicated a high 
concentration of naphthalene (58.3\% at 10-20 cm depth and $49 \%$ at $20-30 \mathrm{~cm}$ depth), but relatively low phenanthrene concentration.

Possible explanations for the dissimilarities include diverse sorption capacity in the soils at sampling sites and different organic carbon content and mineral composition. Naphthalene frequently occurred in the $0-10 \mathrm{~cm}$ interval (min: 0.12 and max: $2.33 \mu \mathrm{g} / \mathrm{kg}$ ) followed by phenanthrene (min: 0.63 and $\max : 1.6 \mu \mathrm{g} / \mathrm{kg}$ ), and fluoranthene (min: 0.50 and max: $2.96 \mu \mathrm{g} / \mathrm{kg}$ ). Soil particles with PAHs adsorbed on the surface can be transported into the deeper intervals within the soil column by recharge water or tilling of soil. The concentrations of all $\Sigma \mathrm{PAH}_{16}$ were low in the deeper layers $(10-20 \mathrm{~cm}$ and $20-30 \mathrm{~cm})$ compared to the surface soils. These variations in PAH distribution can be established by comparing the PAH profiles. While the medium molecular weight (MMW) PAHs, i.e. primarily anthracene and fluoranthene, are transported mainly in the particle-bound state, transport of naphthalene and phenanthrene occurs preferably in the dissolved or gaseous states. The concentrations of some of the lower molecular weight (LMW) (naphthalene and phenanthrene) and MMW (fluoranthene) PAHs show significant positive correlation with the organic carbon content $\left(\mathrm{r}_{\mathrm{nap}}=0.91, \mathrm{r}_{\mathrm{phe}}=0.84\right.$, and $\left.\mathrm{r}_{\mathrm{flu}}=0.89, \mathrm{p}<0.05\right)$. No significant correlation occurred between the higher molecular weight (HMW) PAHs and organic carbon in the whole study area. Adsorption of PAHs from topsoil was due to the organic carbon content, which adsorbed PAHs quite efficiently; only a small percentage of PAHs which pass through the surface are eventually transported into the deeper sub-surface layers.

\section{Sorption experiment sand PAHs isotherms}

Amongst the 25 sediment samples, in 13 samples, kaolinite was dominant. Muscovite and illite were the commonly occurring minerals in most of the samples. Seven samples from the southern part of the lower Ganges river basin showed high quartz content. Sorption study 
for naphthalene and fluoranthene showed higher adsorption on quartz dominated sediments and laboratory-grade quartz. However, phenanthrene showed higher adsorption on kaolinite dominated sediment samples and laboratory-grade kaolinite. The present study indicated linear adsorption and distribution co-efficient after normalization to the specific surface area. Monolayer adsorption of naphthalene and fluoranthene on quartz were evident. The previous research showed that cation- $\pi$ interaction played an essential role in enhancing the sorption of PAHs to sediments primarily on kaolinite (Herbert et al., 2004)Cation- $\pi$ bonding between free metal ions and electron-rich aromatic structures were well acknowledged ${ }^{[35,36]}$. Isotherms for the three PAHs indicate that the Langmuir isotherm model was best for explaining the observed trends . All the isotherm parameters for naphthalene, phenanthrene, and fluoranthene are listed in table 7S-9S. The results of the experimentation and computation analysis of kinetic modeling of adsorption of naphthalene, phenanthrene, and fluoranthene contaminated sediments help to understand the sorption processes in sedimentary environments. The adsorption isotherms of $\Sigma \mathrm{PAH}_{3}$ to kaolinite and quartz dominated sediments are presented in Figure 1S-3S.

The experiments indicated that ca. $66.6 \%$ of naphthalene adsorbed by $30 \mathrm{hrs}$ on quartz dominated natural sediment. After this, the desorption phenomenon was observed (Figure 1S). A similar pattern was observed for laboratory-grade quartz. Kaolinite showed very low adsorption of naphthalene compared to quartz (8.9\% at $30 \mathrm{hrs})$.

About $70 \%$ of fluoranthene was adsorbed by $30 \mathrm{hrs}$ on quartz dominated natural sediment. After this, the desorption phenomenon was observed ( Figure 2S). A similar pattern was observed for laboratory-grade quartz. Kaolinite showed very less adsorption of naphthalene compared to quartz ( $9 \%$ at $30 \mathrm{hrs})$. Unlike naphthalene and fluoranthene, phenanthrene did not show any adsorption on quartz dominated sediment samples. Sorption 
intensity indicated that soft transitional metal ions $\left(\mathrm{Al}^{3+}\right)$ generally favor the sorption of aromatic structures, which is consistent with cation $-\pi$ sorption mechanisms ${ }^{[36]} \cdot \mathrm{Na}^{+}, \mathrm{Al}^{3+}$, and $\mathrm{Mg}^{2+}$ which are dominant in kaolinite-rich sediment are primarily involved in such bonding. Therefore, the adsorption experiment for phenanthrene indicated different results from naphthalene and fluoranthene (Fig. 3S).

The organic carbon content in sediment samples, showed a significant correlation with PAHs . Among other physico-chemical parameters, organic carbon content is one of the crucial factors that may control the adsorption capacity of PAHs onto sediments ${ }^{[37]}$. For the adsorption process, equilibrium was attained faster in case of kaolinite than quartz for phenanthrene. The sorption process followed the first-order reaction kinetics. Based on the amount adsorbed and given the equal time needed for equilibrium to be attained, kaolinite can be described as a better adsorbing agent for phenanthrene.

The LMW naphthalene indicated better adsorption on quartz-rich sediments. The differences in sorption properties of fine-grained sediments (e.g., clay) in comparison to coarser sediments (sand) can be attributed to conducive hydraulic and surface properties. Quartz usually had medium to high porosity and very high permeability. Clay particles may have high porosity, but permeability is low ${ }^{[38]}$. As a result, water molecules lodged in between the clay particles may be associated with the contaminant solutes. Hence, hydraulic properties of sediments, e.g. porosity and permeability, can be an influential parameter in the presence of a potential volume of PAHs and other existing organic compounds.

\section{Statistical analyses}

Four major clusters were generated based on HCA to denote similarity and dissimilarity assessment among the sampling sites (Fig. 4S). Group one is made up of two districts namely Nadia and North-24 Parganas with the highest concentration of total PAHs and low molecular 
weight-PAHs (primarily naphthalene). The second and third groups include South 24 Parganas including Kolkata with intermediate PAH concentrations. Group IV includes Murshidabad and few parts of South 24 Parganas with the lowest level of LMW PAHs; medium and high molecular weight PAHs were mostly absent. The study also includes control sites that are free from anthropogenic activity such as industrial influence and minimal vehicular traffic. The PAH input at these sites are mainly due to domestic waste incineration and disposal of sewage waste.

The highest concentration of total PAHs $\left(\Sigma \mathrm{PAH}_{3}\right)$ occurs in Group I (Nadia and North 24-Parganas), whereas the South 24-Parganas belong to Group II. The control site was the area with the lowest total PAH concentration and was classified as Group III, which primarily belonged to Murshidabad. The effect of flooding and possible dilution might be the reason for the observed differences in the clusters for the two sampling events. Group I indicating agricultural land use indicated the dominance of low molecular weight of PAHs The southern part of the study area which comprises of urban areas including Kolkata and location of nearby petroleum refineries indicated high molecular weight of PAHs of petrogenic origin. PAHs of pyrogenic rarely include vehicular emissions. Therefore, agricultural and peri-urban areas indicated a higher abundance of low molecular weight PAHs, i.e. naphthalene, unlike the urban regions.

The Western Bengal basin mostly consists of clay minerals, and southern parts of the basin are dominated by sand and silt. Sediments collected from the peri-urban areas of South 24 Parganas contain a higher amount of naphthalene. However, clay-dominated sediment samples collected from Nadia and North 24 Parganas indicated higher concentrations of phenanthrene and fluoranthene. The present results indicated significant differences in the PAH concentrations in sediment samples. $\mathrm{PAH}$ ratios, such as $\mathrm{An} /(\mathrm{An}+\mathrm{Phe})$ and $\mathrm{Flu} /(\mathrm{Flu}+\mathrm{Py})$, calculated imply presence of both pyrogenic and petrogenic PAH inputs ${ }^{[39-41]}$. An/(An+Phe) 
ratio $<0.1$ suggests a petrogenic provenance for PAHs, whereas values $>0.1$ suggest pyrogenic PAHs. Flu/(Flu + Py $)$ ratio $<0.4$ are derived from petrogenic source and $>0.5$ indicate pyrogenic sources ${ }^{[42]}$. In the present study, $\mathrm{An} /(\mathrm{An}+\mathrm{Phe})$ ratios for six sediment samples SS5, SS7, SS9, SS19, SS21, and SS23 were lower than 0.1, which suggests some of the major sources of petrogenic PAHs can be released from motor oil, gasoline and other substances associated with vehicular transport and emissions. However, the rest of the sediment samples indicated the presence of pyrogenic PAHs. Pyrolytically formed material usually converts into more stable six-member rings PAHs (Fig. 5). Flu/(Flu+Py) ratio in five sediment sites (SS6, SS8, SS20, SS21 and SS22) was less than 0.4 which suggests that the PAHs sources were of petrogenic origin, whereas the other fifteen sediment samples showed pyrolytic PAHs. Five samples showed the Flu/ (Flu+Py) ratio within 0.4 and 0.5 (SS2, SS5, SS7, SS9, and SS23) which suggests the combustion of petroleum products as the source of these PAHs.

It has been observed that sediment samples from the South 24 Parganas were contaminated with PAHs due to petroleum spills in the recent past (Mitra et al., ${ }^{[14]}$ ). In contrast, PAHs sources in sediment samples from other districts were derived either from incomplete combustion of woods or from the local release of motor oil (vehicular emissions from incomplete combustion). It is proposed from the sorption kinetics that naphthalene is adsorbed to quartz, and as a result, naphthalene concentration is higher in sediments dominated by sand situated in the southern part of the Western Bengal basin. The urban areas in Nadia and North 24 Parganas showed a higher amount of phenanthrene in kaolinite dominated sediments. This trend is consistent with the results obtained from the sorption study.

\section{Impact of pumping on PAH pollution}

Advective transport modeling for PAHs particle shows the migration of these compounds in an aquifer under existing simulated groundwater flow conditions across the study area. The 
present study on the influence of irrigational pumping on PAH distribution was hypothesized with imaginary conservative contaminant particles to simulate advective transport ina contaminated public drinking water well in an area found to be the most contaminated and hydraulically vulnerable to PAH contamination as reported earlier ${ }^{[43]}$. Assuming the PAH molecule as a conservative contaminant particle, the model assessed the vulnerability of the aquifer to contamination. As per the regional flow simulation, the presented and projected pumping scenarios indicated a cone of depression with a vertical gradient of up to $\sim 0.25 \mathrm{~m} / \mathrm{m}$ at present which is expected to increase up to $\sim 0.36 \mathrm{~m} / \mathrm{m}$ under the present rate of groundwater withdrawl (Mukherjee et al., ${ }^{[18]}$ ).

The simulated site is located near Kamgachi village in Nadia district (Fig. 6). In this area, the present-day annual pumping rates from public drinking water wells are $\sim 100 \mathrm{~m}^{3} / \mathrm{h}$ for 6 $\mathrm{h}$ /day; pumping rates in heavy-duty mechanized irrigation wells are $150-200 \mathrm{~m}^{3} / \mathrm{hr}$ for $6-15$ $\mathrm{hr} /$ day and varies seasonally. Simulated hypothetical particles from depths of near-surface to $>50 \mathrm{~m}$ below land surface in the vertical direction, and up to $\sim 75 \mathrm{~m}$ horizontal distance, could advectively travel to the target depth of the water source, which is up to 20-25 times faster under an induced vertical hydraulic gradient (Fig. 6). This clearly suggests that the pervasive irrigational pumping which is a common practice in the study area could be a potential reason for the transport of PAHs, as it enters into the sub-surface by natural hydrological processes like groundwater recharge. The presence of hypothetical particles emphasizes the advective transport of solutes by groundwater during the simulation for groundwater pumping. This trend demonstrated the potential of PAH molecules being transported from a near-surface (associated with agricultural or industrial activities) to potable groundwater abstraction depths ranging from $\sim 15 \mathrm{~m}$ to $>150 \mathrm{mbgl}$ (meter below ground level) in the study sites. The simulation provides an insight into the potential causes of PAH pollution in agricultural and industrial areas in the region that can be extended to other sites as a monitoring tool. 


\section{Conclusions}

The distribution and advective transport of anthropogenic-sourced PAH pollution in aquifers extending over $\sim 21,000 \mathrm{~km}^{2}$ of the lower reaches of the Ganges river basin, were studied in order to understand the availability of safe and sustainable groundwater-sourced drinking water in an area. This area is already exposed to wide-scale geogenic groundwater arsenic pollution. All sampled waters were found to have at least one or more of the 16 priority PAHs [e.g., naphthalene $(4.9-10.6 \mu \mathrm{g} / \mathrm{L})$, phenanthrene $(3.32-6.61 \mu \mathrm{g} / \mathrm{L})]$. Naphthalene, phenanthrene and fluoranthene were detected in 79,36 and $13 \%$ of the sampled sediments $(n=25)$ in the area. The lithological setting of the lower Ganges River basin consists of four major types of unconsolidated sediments: gravel, clay, sand, and silt. The PAH concentrations in the sub-surface soils are generally dominated by naphthalene, followed by phenanthrene. PAH concentrations in the top soil $(0-10 \mathrm{~cm})$, is different from those in the deeper soil intervals $(20-30 \mathrm{~cm})$. The organic carbon content was also higher in surface soils $(0-10 \mathrm{~cm})$ than the deeper layers. As organic carbon content decreases with depth, the adsorption of PAHs decreases. The present study indicates that the potential sources of PAHs were primarily of pyrogenic origin in rural agricultural areas. In contrast, PAHs mostly originated from petroleum combustion processes in urban areas.

Sorption behavior and advective transport of PAH help to develop a mechanistic understanding of the contaminant transport that is influenced by dominant minerals in the sediment matrix (i.e., quartz (sand) vs. clay minerals), sediment characteristics (carbon content), and land use ( agriculture, peri-urban and urban areas). The numerically simulated advective transport mechanism in a well-investigated aquifer within the study area (cite the ref here), was found to be vulnerable to PAH pollution. Transport of PAH from the surface to a 
drinking water target depth, suggests up to $\sim 25$ times faster movement of the contaminant particle under influence of irrigation-induced pumping regimes.

Besides providing a possible explanation for regional and local patterns in the distribution of PAHs in shallow aquifers, our observations have two practical inferences. First, the study represents the sorption of PAHs on predominant minerals in aquifer sediments which would influence the distribution of PAHs. In particular, the different physicochemical properties in sediments indicate the influence on migration of PAHs. Secondly, the mobility of PAHs in groundwater wells is affected by irrigational pumping. The hypothetical advective transport modeling indicates the development of a depression cone during pumping which enhances PAHs transport. These two scenarios can help in assessing the overall vulnerability of PAH contamination in the study area.

The study highlights the correlation between aquifer sediment properties, land use, and $\mathrm{PAH}$ contamination. In particular, groundwater abstraction practices and use can have a significant impact on redistribution and spreading of anthropogenic pollutants including PAHs in the sub-surface. Implementation of legislation and other activities to restrict the use of solid fuels for domestic purposes may reduce the PAH emissions and deposition on surface sediments and provides vision on groundwater monitoring and assessment.

\section{Acknowledgements}

We thank the Public Health Engineering Department, Government of West Bengal (PHED), and Water supply and sanitation organization (WSSO) for their cooperation and assistance during field work. The ideas and views expressed in this paper are solely those of the authors and have not been endorsed by any other person or agency. The work was 
financially supported by PHED, Govt. of West Bengal and STINT (Grant IB2015-6031). The authors express their gratitude to the School of Environmental Science and Engineering, IITKharagpur. Special thanks to Avishek Dutta for his support in technical writing. SDG would like to thank Kousik Das and her colleagues at IIT-Kharagpur for their support. Authors are thankful to Viji John, Lena Lundman and Sussanne Karlsson for their fantastic support and inputs for the experimental work.

\section{References}

[1] Cordner, A.; Vanessa, Y.; Schaider, L.A.; Rudel, R.A.; Richter, L.; Brown, P. Guideline levels for PFOA and PFOS in drinking water: the role of scientific uncertainty, risk assessment decisions, and social factors. Journal of exposure science \& environmental epidemiology 2019, 29(2), 157.

[2] Petousi, I.; Fountoulakis, M.S.; Tzortzakis, N.; Dokianakis, S.; Stentiford, E.I.; Manios, T. Occurrence of Micro-pollutants in a Soil-Radish System Irrigated with Several Types of Treated Domestic Wastewater. Water, Air, \& Soil Pollution 2014, 225(1), 1791.

[3] Susarla, S.; Medina, V.F.; McCutcheon, S.C. Phytoremediation: an ecological solution to organic chemical contamination. Ecological Engineering 2002, 18(5), 647-658.

[4] Edokpayi, J.N.; Odiyo, J.O.; Popoola, O.E.; Msagati, T.A. Determination and distribution of polycyclic aromatic hydrocarbons in rivers, sediments and wastewater effluents in Vhembe District, South Africa. International journal of environmental research and public health 2016, 13(4), 387.

[5] Fewson, C.A. Biodegradation of xenobiotic and other persistent compounds: the causes of recalcitrance. Trends in biotechnology 1988, 6(7), 148-153.

[6] Collins, P.C.; Nielsen, L.K.; Patel, S.D.; Papoutsakis, E.T.; Miller, W.M. Characterization of hematopoietic cell expansion, oxygen uptake, and glycolysis in a controlled, stirred-tank bioreactor system. Biotechnology progress 1998, 14(3), 466-472.

[7] Johnsen, A.R.; Wick, L.Y.; Harms, H. Principles of microbial PAH-degradation in soil. Environmental pollution 2005, 133(1), 71-84.

[8] Wang, X.-T.; Miao, Y.; Zhang, Y.; Li, Y.-C.; Wu, M.-H.; Yu, G. Polycyclic aromatic hydrocarbons (PAHs) in urban soils of the megacity Shanghai: occurrence, source apportionment and potential human health risk. Science of the Total Environment 2013, 447, $80-89$.

[9] Jonker, M.T.; Koelmans, A.A. Sorption of polycyclic aromatic hydrocarbons and polychlorinated biphenyls to soot and soot-like materials in the aqueous environment: mechanistic considerations. Environmental science \& technology 2002, 36(17), 3725-3734. 
[10] Christensen, E.R.; Bzdusek, P.A. PAHs in sediments of the Black River and the Ashtabula River, Ohio: source apportionment by factor analysis. Water Research 2005, 39(4), 511-524.

[11] Ballesteros-Gómez, A.; Sicilia, M.D.; Rubio, S. Supramolecular solvents in the extraction of organic compounds. A review. Analytica Chimica Acta 2010, 677(2), 108-130.

[12] Zhang, Y.; Guo, C.-S.; Xu, J.; Tian, Y.-Z.; Shi, G.-L.; Feng, Y.-C. Potential source contributions and risk assessment of PAHs in sediments from Taihu Lake, China: comparison of three receptor models. Water research 2012, 46(9), 3065-3073.

[13] Man, Y.B.; Kang, Y.; Wang, H.S.; Lau, W.; Li, H.; Sun, X.L.; Giesy, J.P.; Chow, K.L.; Wong, M.H. Cancer risk assessments of Hong Kong soils contaminated by polycyclic aromatic hydrocarbons. Journal of Hazardous Materials 2013, 261, 770-776.

[14] Mitra, S.; Corsolini, S.; Pozo, K.; Audy, O.; Sarkar, S.K.; Biswas, J.K. Characterization, source identification and risk associated with polyaromatic and chlorinated organic contaminants (PAHs, PCBs, PCBzs and OCPs) in the surface sediments of Hooghly estuary, India. Chemosphere 2019, 221, 154-165.

[15] Chakraborty, M.; Mukherjee, A.; Ahmed, K.M. A review of groundwater arsenic in the Bengal Basin, Bangladesh and India: from source to sink. Current Pollution Reports 2015, 1(4), 220-247.

[16] Mukherjee, A.; Saha, D.; Harvey, C.F.; Taylor, R.G.; Ahmed, K.M.; Bhanja, S.N. Groundwater systems of the Indian sub-continent. Journal of Hydrology: Regional Studies 2015, 4, 1-14.

[17] Smith, A.H.; Lingas, E.O.; Rahman, M. Contamination of drinking-water by arsenic in Bangladesh: a public health emergency. Bulletin of the World Health Organization 2000, 78, 1093-1103.

[18] Mukherjee, A.; Fryar, A.E.; Howell, P.D. Regional hydrostratigraphy and groundwater flow modeling in the arsenic-affected areas of the western Bengal basin, West Bengal, India. Hydrogeology Journal 2007, 15(7), 1397.

[19] Pinto, A.; Rodrigues, S.; Caldeira, A.; Teixeira, D. Exploring the potential of novel biomixtures and Lentinula edodes fungus for the degradation of selected pesticides. Evaluation for use in biobed systems. Science of the Total Environment 2016, 541, 1372-1381.

[20] Zhao, J.; Tian, W.; Liu, S.; Wang, Z.; Du, Z.; Xie, W. Existence, removal and transformation of parent and nitrated polycyclic aromatic hydrocarbons in two biological wastewater treatment processes. Chemosphere 2019, 224, 527-537.

[21] Yang, T.; Cheng, H.; Wang, H.; Drews, M.; Li, S.; Huang, W.; Zhou, H.; Chen, C.M.; Diao, X. Comparative study of polycyclic aromatic hydrocarbons (PAHs) and heavy metals (HMs) in corals, surrounding sediments and surface water at the Dazhou Island, China. Chemosphere 2019, 218, 157-168.

[22] Eberl, D.D.; Srodon, J.; Drits, V.A. Comment on "Evaluation of X-ray diffraction methods for determining the crystal growth mechanisms of clay minerals in mudstones, shales and slates," by LN Warr and DL Peacor. Schweizerische Mineralogische Petrographische Mitteilungen 2003, 83, 349-351. 
[23] Madsen, L.; Lindhardt, B.; Rosenberg, P.; Clausen, L.; Fabricius, I. Pesticide sorption by low organic carbon sediments: a screening for seven herbicides. Journal of Environmental Quality 2000, 29(5), 1488-1500.

[24] Carmo, A.M.; Hundal, L.S.; Thompson, M.L. Sorption of hydrophobic organic compounds by soil materials: application of unit equivalent Freundlich coefficients. Environmental Science \& Technology 2000, 34(20), 4363-4369.

[25] Weber, W.J.; Borchardt, J.A. Physicochemical processes for water quality control. WileyInterscience New York: , 1972.

[26] Haynes, W. Student's t-test. Encyclopedia of Systems Biology 2013, 2023-2025.

[27] Myers, L.; Sirois, M. Wiley StatsRef: Statistics Reference Online. 2006.

[28] Hair, J.F.; Black, W.; Babin, B.; Anderson, R.; Tatham, R. Multivariate data analysis (Vol. 5, No. 3, pp. 207-219). 1998.

[29] McDonald, M.G.; Harbaugh, A.W. A modular three-dimensional finite-difference groundwater flow model. US Geological Survey Reston, VA: , 1988.

[30] Pollock, D.W. User's Guide for MODPATH/MODPATH-PLOT, Version 3: A Particle Tracking Post-processing Package for MODFLOW, the US: Geological Survey Finitedifference Ground-water Flow Model. 1994.

[31] Koh, C.-H.; Khim, J.; Kannan, K.; Villeneuve, D.; Senthilkumar, K.; Giesy, J. Polychlorinated dibenzo-p-dioxins (PCDDs), dibenzofurans (PCDFs), biphenyls (PCBs), and polycyclic aromatic hydrocarbons (PAHs) and 2, 3, 7, 8-TCDD equivalents (TEQs) in sediment from the Hyeongsan River, Korea. Environmental Pollution 2004, 132(3), 489-501.

[32] Khairy, M.A.; Kolb, M.; Mostafa, A.R.; Anwar, E.-F.; Bahadir, M. Risk assessment of polycyclic aromatic hydrocarbons in a Mediterranean semi-enclosed basin affected by human activities (Abu Qir Bay, Egypt). Journal of hazardous materials 2009, 170(1), 389-397.

[33] Scolnick, M.; John, G.S.; Anbar, M. In Application Of Field Ionization Mass Spectrometry 9 To The Characterization Of Coal Liquefaction Products, Proceedings Of The Coal Chemistry Workshop, 1976.

[34] Augustave, L.C. Study of treated and untreated oil based drilling waste using a biomarker approach: gill and liver histopathology in Atlantic salmon (Salmo salar). 2014.

[35] Ma, J.C.; Dougherty, D.A. The cation- $\pi$ interaction. Chemical reviews 1997, 97(5), $1303-1324$.

[36] Neela, Y.I.; Mahadevi, A.S.; Sastry, G.N. First principles study and database analyses of structural preferences for sodium ion $(\mathrm{Na}+)$ solvation and coordination. Structural Chemistry 2013, 24(1), 67-79.

[37] Means, J.C.; Wood, S.G.; Hassett, J.J.; Banwart, W.L. Sorption of polynuclear aromatic hydrocarbons by sediments and soils. Environmental Science \& Technology 1980, 14(12), $1524-1528$. 
[38] Klimentos, T.; McCann, C. Relationships among compressional wave attenuation, porosity, clay content, and permeability in sandstones. Geophysics 1990, 55(8), 998-1014.

[39] Yunker, M.B.; Macdonald, R.W.; Vingarzan, R.; Mitchell, R.H.; Goyette, D.; Sylvestre, S. PAHs in the Fraser River basin: a critical appraisal of PAH ratios as indicators of PAH source and composition. Organic geochemistry 2002, 33(4), 489-515.

[40] Magi, E.; Bianco, R.; Ianni, C.; Di Carro, M. Distribution of polycyclic aromatic hydrocarbons in the sediments of the Adriatic Sea. Environmental pollution 2002, 119(1), 9198.

[41] Chen, Y.; Evans, J.; Feldlaufer, M. Horizontal and vertical transmission of viruses in the honey bee, Apis mellifera. Journal of invertebrate pathology 2006, 92(3), 152-159.

[42] Dong, C.-D.; Chen, C.-F.; Chen, C.-W. Determination of polycyclic aromatic hydrocarbons in industrial harbor sediments by GC-MS. International journal of environmental research and public health 2012, 9(6), 2175-2188.

[43] Mukherjee, A.; Fryar, A.E.; Scanlon, B.R.; Bhattacharya, P.; Bhattacharya, A. Elevated arsenic in deeper groundwater of the western Bengal basin, India: Extent and controls from regional to local scale. Applied Geochemistry 2011, 26(4), 600-613.

[44] Fernandes, M.; Sicre, M.-A.; Boireau, A.; Tronczynski, J. Polyaromatic hydrocarbon (PAH) distributions in the Seine River and its estuary. Marine Pollution Bulletin 1997, 34(11), $857-867$.

[45] Benlahcen, K.; Chaoui, A.; Budzinski, H.; Bellocq, J.; Garrigues, P. Distribution and sources of polycyclic aromatic hydrocarbons in some Mediterranean coastal sediments. Marine Pollution Bulletin 1997, 34(5), 298-305.

[46] Baumard, P.; Budzinski, H.; Michon, Q.; Garrigues, P.; Burgeot, T.; Bellocq, J. Origin and bioavailability of PAHs in the Mediterranean Sea from mussel and sediment records. Estuarine, Coastal and Shelf Science 1998, 47(1), 77-90.

[47] Zhu, X.; Liu, W.; Lu, Y.; ZHU, T. Study on the characteristics of PAHs source profile of coal combustion. Research of Environmental Sciences 2001, 14(5), 4-8.

[48] Telli-Karakoç, F.; Tolun, L.; Henkelmann, B.; Klimm, C.; Okay, O.; Schramm, K.-W. Polycyclic aromatic hydrocarbons (PAHs) and polychlorinated biphenyls (PCBs) distributions in the Bay of Marmara sea: Izmit Bay. Environmental Pollution 2002, 119(3), 383-397.

[49] Viguri, J.; Verde, J.; Irabien, A. Environmental assessment of polycyclic aromatic hydrocarbons (PAHs) in surface sediments of the Santander Bay, Northern Spain. Chemosphere 2002, 48(2), 157-165.

[50] Readman, J.; Fillmann, G.; Tolosa, I.; Bartocci, J.; Villeneuve, J.-P.; Catinni, C.; Mee, L. Petroleum and PAH contamination of the Black Sea. Marine pollution bulletin 2002, 44(1), $48-62$.

[51] Fang, G.-C.; Chang, K.-F.; Lu, C.; Bai, H. Toxic equivalency factors study of polycyclic aromatic hydrocarbons (PAHs) in Taichung City, Taiwan. Toxicology and industrial health 2002, 18(6), 279-288. 
[52] De Luca, G.; Suryapranata, H.; Ottervanger, J.P.; Antman, E.M. Time delay to treatment and mortality in primary angioplasty for acute myocardial infarction: every minute of delay counts. Circulation 2004, 109(10), 1223-1225.

[53] Hartmann, P.C.; Quinn, J.G.; Cairns, R.W.; King, J.W. The distribution and sources of polycyclic aromatic hydrocarbons in Narragansett Bay surface sediments. Marine Pollution Bulletin 2004, 48(3-4), 351-358.

[54] Malik, A.; Singh, K.; Mohan, D.; Patel, D. Distribution of polycyclic aromatic hydrocarbons in Gomti river system, India. Bulletin of environmental contamination and toxicology 2004, 72(6), 1211-1218.

[55] Agarwal, T.; Khillare, P.; Shridhar, V. PAHs contamination in bank sediment of the Yamuna River, Delhi, India. Environmental Monitoring and Assessment 2006, 123(1-3), 151166.

[56] Martínez-Lladó, X.; Gibert, O.; Martí, V.; Díez, S.; Romo, J.; Bayona, J.M.; Pablo, J. de. Distribution of polycyclic aromatic hydrocarbons (PAHs) and tributyltin (TBT) in Barcelona harbour sediments and their impact on benthic communities. Environmental Pollution 2007, 149(1), 104-113.

[57] Men, B.; He, M.; Tan, L.; Lin, C.; Quan, X. Distributions of polycyclic aromatic hydrocarbons in the Daliao River estuary of Liaodong Bay, Bohai Sea (China). Marine Pollution Bulletin 2009, 58(6), 818-826.

[58] Pereira, R.G.; Heinemann, A.B.; Madari, B.E.; Carvalho, M.T. de M.; Kliemann, H.J.; Santos, A.P. dos. Transpiration response of upland rice to water deficit changed by different levels of eucalyptus biochar. Pesquisa Agropecuária Brasileira 2012, 47(5), 716-721.

[59] Luo, L.; Lin, S.; Huang, H.; Zhang, S. Relationships between aging of PAHs and soil properties. Environmental Pollution 2012, 170, 177-182.

[60] Huang, W.; Wang, Z.; Yan, W. Distribution and sources of polycyclic aromatic hydrocarbons (PAHs) in sediments from Zhanjiang Bay and Leizhou Bay, South China. Marine pollution bulletin 2012, 64(9), 1962-1969.

[61] Dudhagara, D.R.; Rajpara, R.K.; Bhatt, J.K.; Gosai, H.B.; Sachaniya, B.K.; Dave, B.P. Distribution, sources and ecological risk assessment of PAHs in historically contaminated surface sediments at Bhavnagar coast, Gujarat, India. Environmental pollution 2016, 213, 338346.

[62] Rajpara, R.K.; Dudhagara, D.R.; Bhatt, J.K.; Gosai, H.B.; Dave, B.P. Polycyclic aromatic hydrocarbons (PAHs) at the Gulf of Kutch, Gujarat, India: Occurrence, source apportionment, and toxicity of PAHs as an emerging issue. Marine pollution bulletin 2017, 119(2), 231-238.

[63] Zanardi-Lamardo, E.; Mitra, S.; Vieira-Campos, A.A.; Cabral, C.B.; Yogui, G.T.; Sarkar, S.K.; Biswas, J.K.; Godhantaraman, N. Distribution and sources of organic contaminants in surface sediments of Hooghly river estuary and Sundarban mangrove, eastern coast of India. Marine Pollution Bulletin 2019, 146, 39-49. 


\section{TABLE CAPTIONS}

2 Table 1: PAHs detected at various study across the world including that at the present site 


\begin{tabular}{|c|c|c|c|}
\hline Location & Range (ng/g) & Mean (ng/g) & References \\
\hline Biscay Bay, France & $20-5159$ & - & Fernandes et al. ${ }^{[44]}$ \\
\hline $\begin{array}{l}\text { Northwest } \\
\text { Mediterranean Sea }\end{array}$ & $86.5-48,090$ & - & Benlahcen et al., ${ }^{[45]}$ \\
\hline West Mediterranean Sea & $1.5-20,440$ & - & Baumard et al., ${ }^{[46]}$ \\
\hline Meizhou Bay, China & $196.7-299.7$ & 256.1 & Zhu et al., ${ }^{[47]}$ \\
\hline $\begin{array}{l}\text { Izmit Bay, Marmara } \\
\text { Sea, Turkey }\end{array}$ & $3.0 \times 10^{4}-1.67 \times 10^{6}$ & $6.01 \times 10^{5}$ & Telli-Karakoç et al., ${ }^{[48]}$ \\
\hline Santander Bay, Spain & $1620-344,600$ & - & Viguri et al., ${ }^{[49]}$ \\
\hline Black Sea coast, Turkey & $10-530$ & - & Readman et al., ${ }^{[50]}$ \\
\hline $\begin{array}{l}\text { Hsin-ta Harbour, } \\
\text { Taiwan }\end{array}$ & $156-3382$ & - & Fang et al., [51] \\
\hline $\begin{array}{l}\text { Porto Torres, Sardinia, } \\
\text { Italy }\end{array}$ & $70-1210$ & - & De Luca et al., [52] \\
\hline Narragansett Bay, USA & $569-216,000$ & 21,100 & Hartmann et al., ${ }^{[53]}$ \\
\hline Gomti River, India & $208-3365$ & & Malik et al., ${ }^{[54]}$ \\
\hline Yamuna River, India & $4,502-23,527$ & 14014.5 & Agarwal et al., ${ }^{[55]}$ \\
\hline $\begin{array}{l}\text { Barcelona Harbour, } \\
\text { Spain }\end{array}$ & $16,300-10,320$ & & $\begin{array}{l}\text { Martínez-Lladó et al., } \\
{[56]}\end{array}$ \\
\hline Liaodong Bay, China & $276.26-1606.89$ & 743.03 & Men et al., ${ }^{[57]}$ \\
\hline San Francisco Bay, USA & $2653-27680$ & & Pereira et al., ${ }^{[58]}$ \\
\hline Leizhou Bay, China & $21.72-319.61$ & 103.91 & Luo et al., ${ }^{[59]}$ \\
\hline Zhanjiang Bay, China & $41.96-933.90$ & 315.98 & Huang et al., ${ }^{[60]}$ \\
\hline Alang-sosiya, India & $5020-981,000$ & 345,000 & Dudhagara et al. ${ }^{[61]}$ \\
\hline Gulf of Kutch, India & $118,280-1,099,410$ & 321,635 & Rajpara et al., ${ }^{[62]}$ \\
\hline $\begin{array}{l}\text { Hooghly river estuary, } \\
\text { India }\end{array}$ & $3.26-628.61$ & 168.28 & Mitra et al., ${ }^{[14]}$ \\
\hline $\begin{array}{l}\text { Sunderbans mangrove, } \\
\text { eastern coast of India }\end{array}$ & 15.4 to 1731 & - & $\begin{array}{l}\text { Zanardi-Lamardo et al., } \\
\text { [63] }\end{array}$ \\
\hline $\begin{array}{l}\text { Western Bengal basin, } \\
\text { India }\end{array}$ & $1.15-23.13$ & 3.68 & Present study \\
\hline
\end{tabular}

4

5

6

7 


\section{FIGURES CAPTIONS}

10 Figure 1. Map showing study area located in India (a) four districts vis-à-vis major rivers in 11 Western Bengal basin in India [blue lines proposed river path] and sediment $(n=25)$ and river 12 water $(\mathrm{n}=32)$ sampling locations; (b) groundwater sampling locations $(\mathrm{n}=235)$

13 Figure 2. Graph showing detection frequencies of detected polycyclic aromatic hydrocarbons 14 (PAHs) for river water and groundwater

Figure 3. Spatial distribution of predominantly detected four PAHs in (a) groundwater and (b) river water, viz. naphthalene, phenanthrene, fluoranthene and anthracene across the Western

17 Bengal basin

Figure 4. Graph showing the PAH concentration $(\mu \mathrm{g} / \mathrm{kg})$ in twenty five sediment samples collected from Western Bengal basin

Figure 5. PAHs cross plot for the ratios of Flu/(Py + Flu $)$ and $\mathrm{An} /(\mathrm{An}+\mathrm{Phe})$

Figure 6. Advective transport of hypothetical PAH particles during pumping 


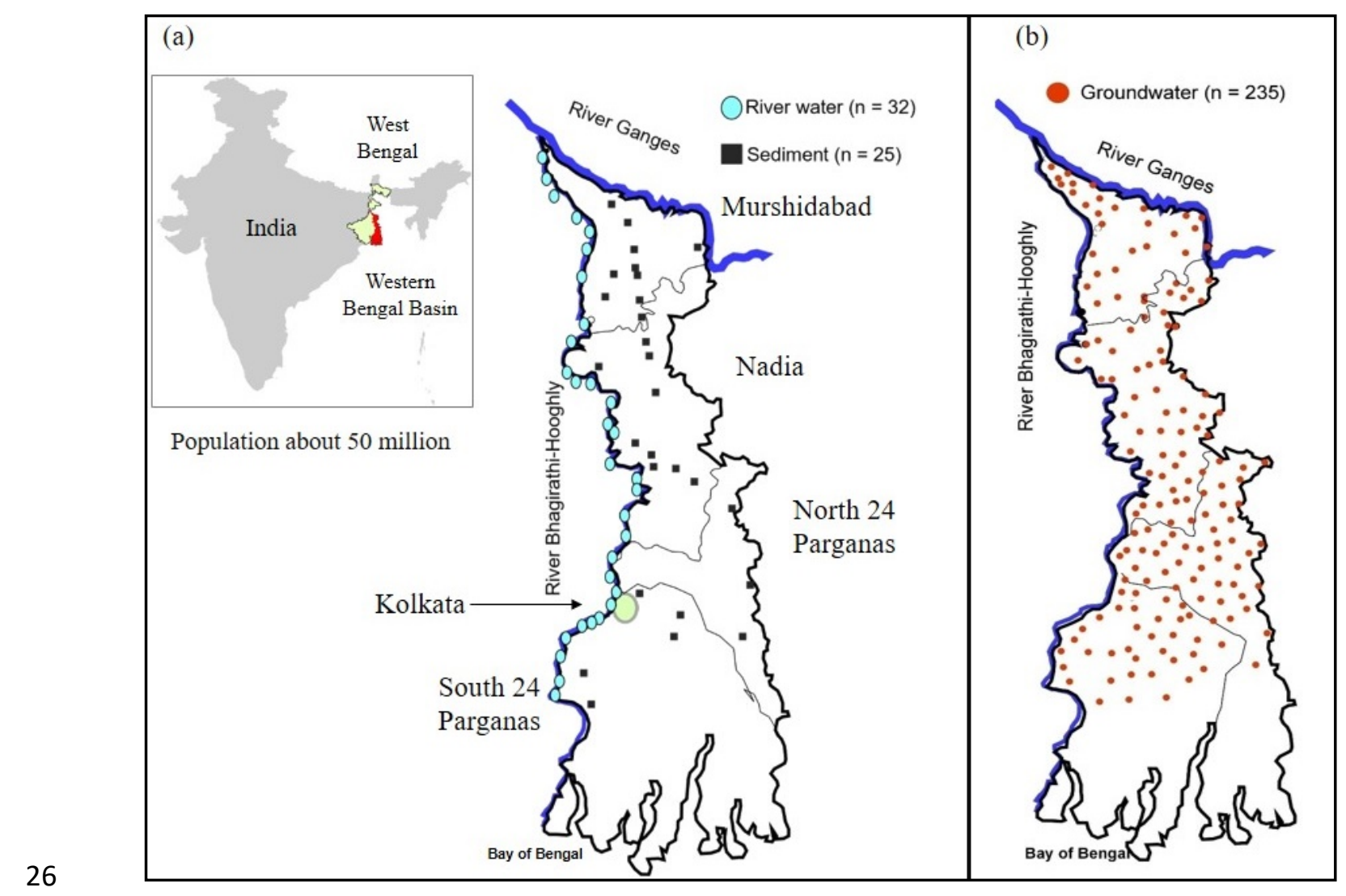

$27 \quad$ Fig. 1 


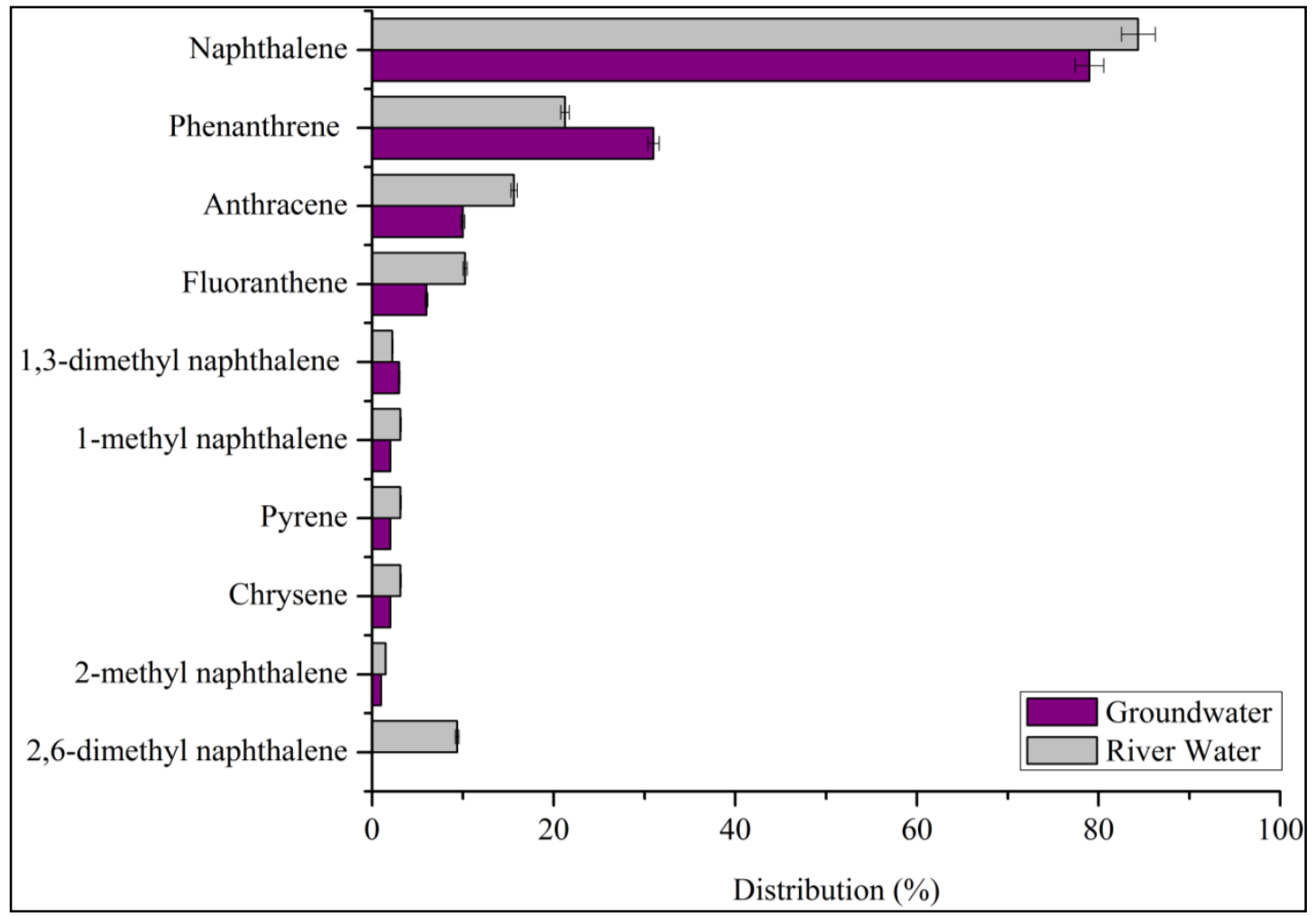

$32 \quad$ Fig. 2

33 


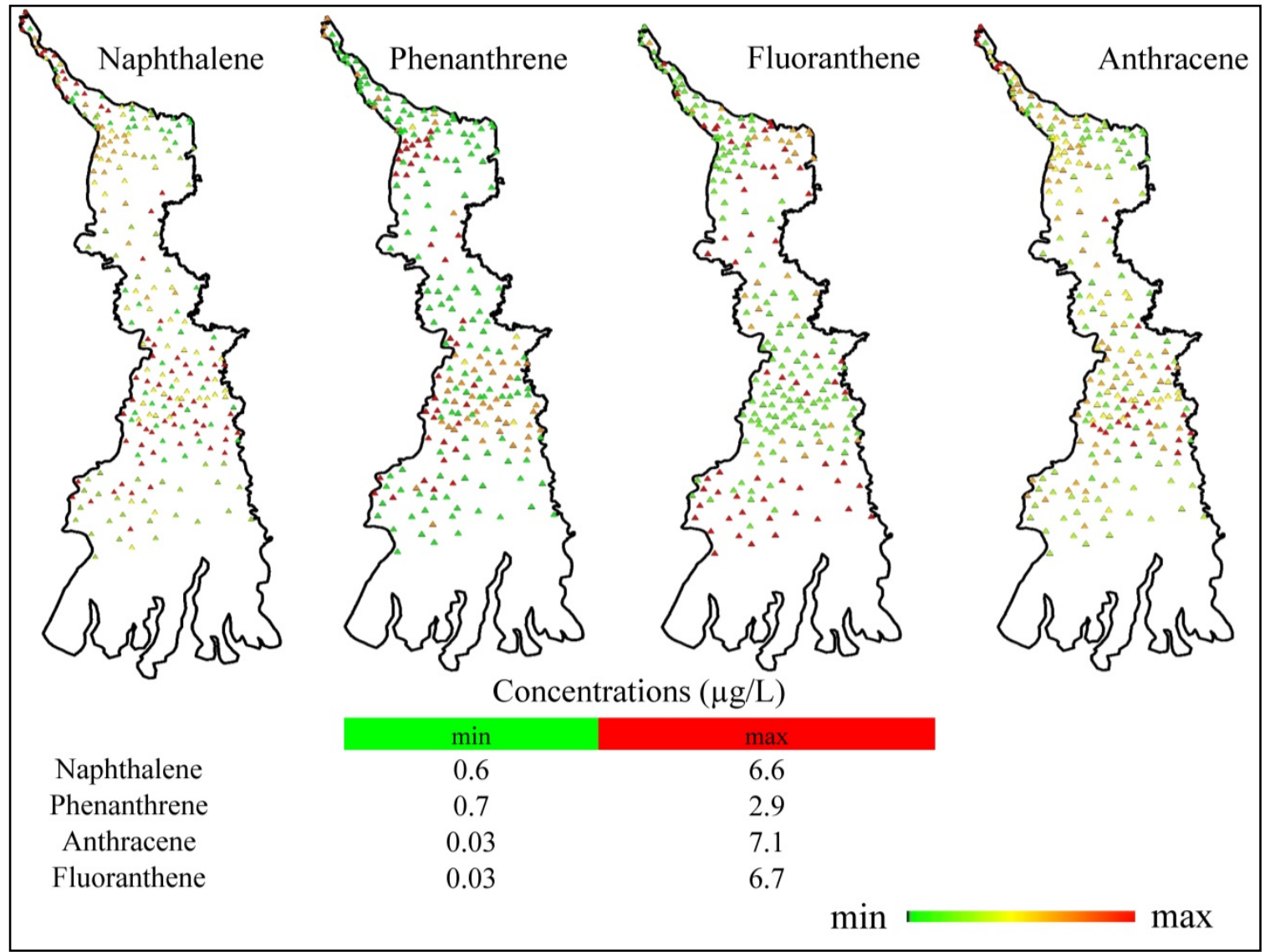

Fig. 3a 

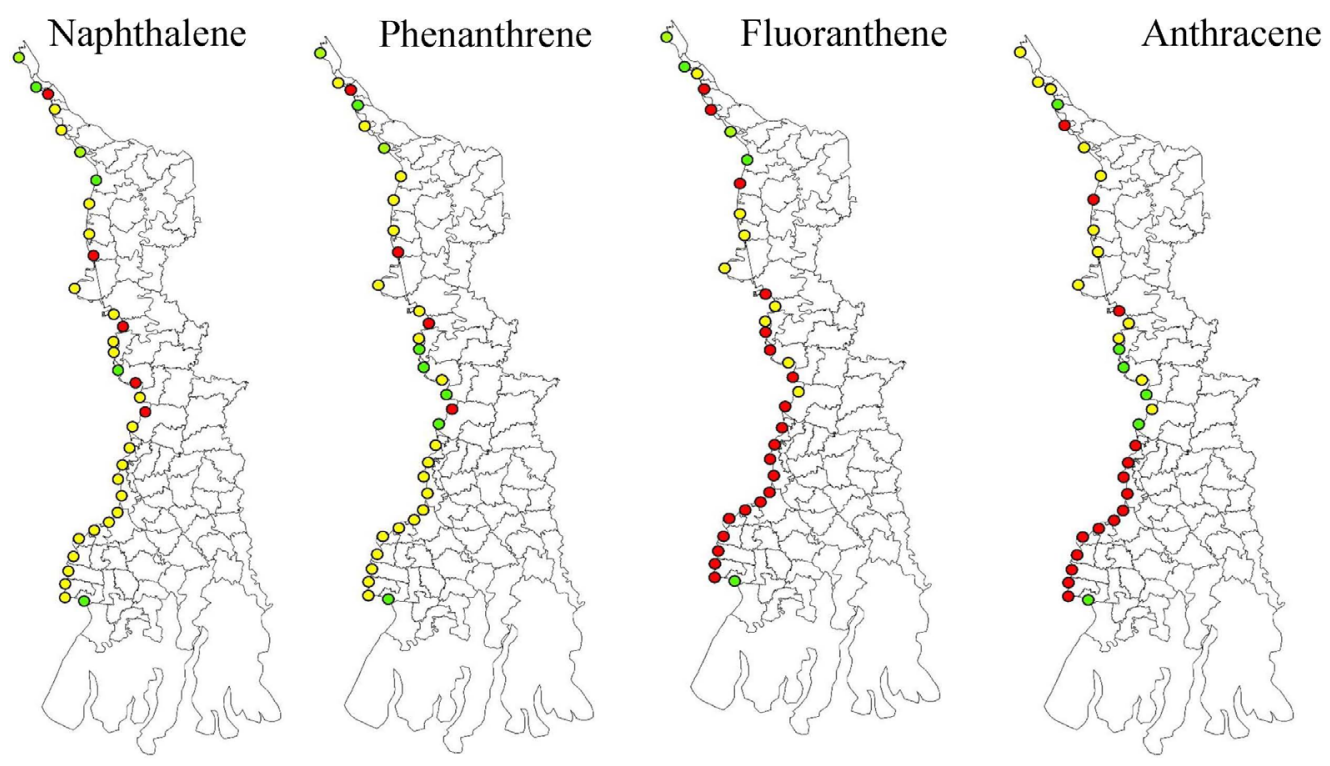

\section{Concentrations $(\mu \mathrm{g} / \mathrm{L})$}

Naphthalene

Phenanthrene

Anthracene

Fluoranthene

$\begin{array}{cc}\min & \max \\ 5.4875 & 16.1 \\ 3.323 & 7.705 \\ 1.19 & 2.175 \\ 3.255 & 4.988\end{array}$

\section{$37 \quad$ Fig. 3b}




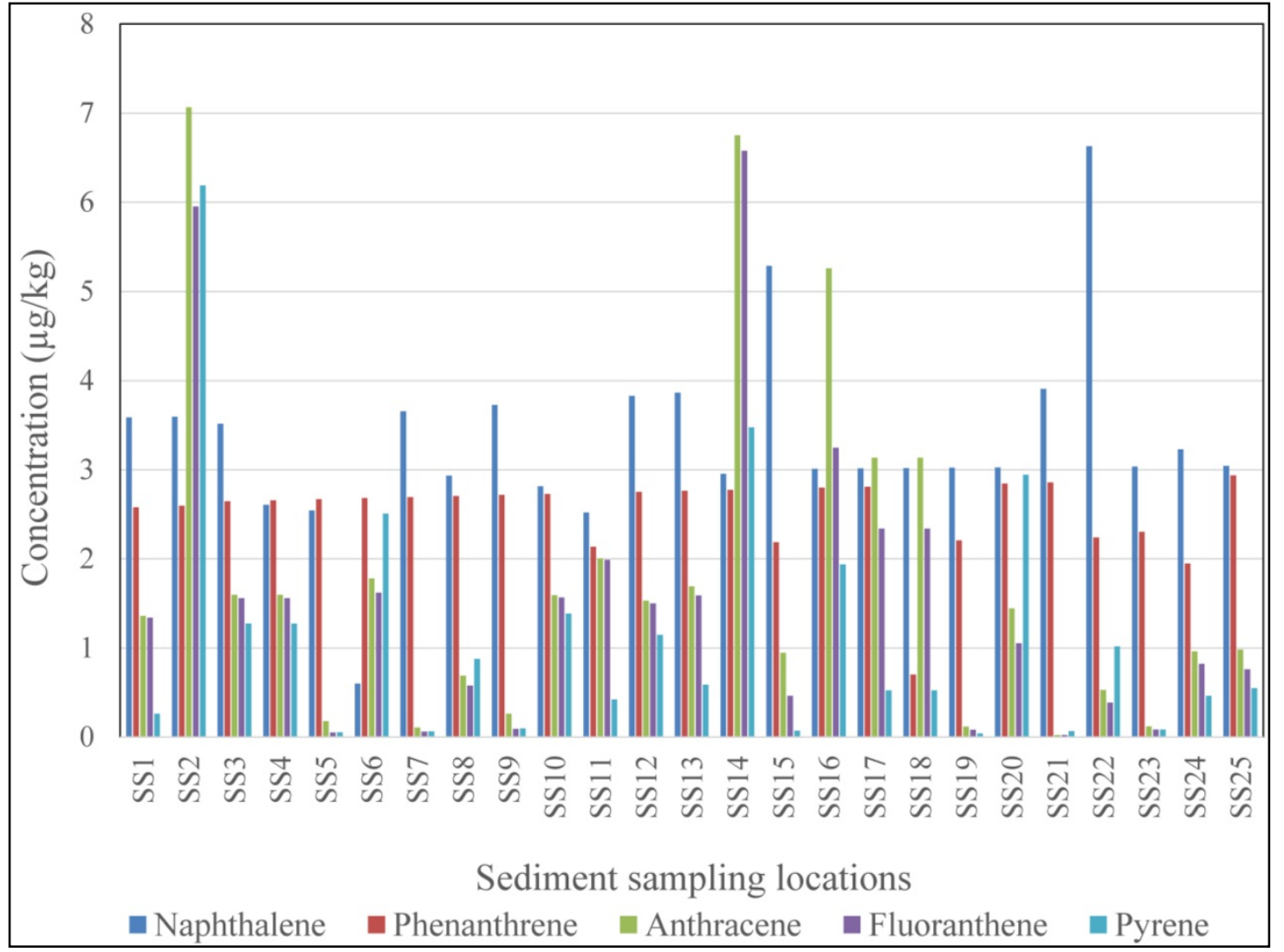

40

Fig. 4

41 


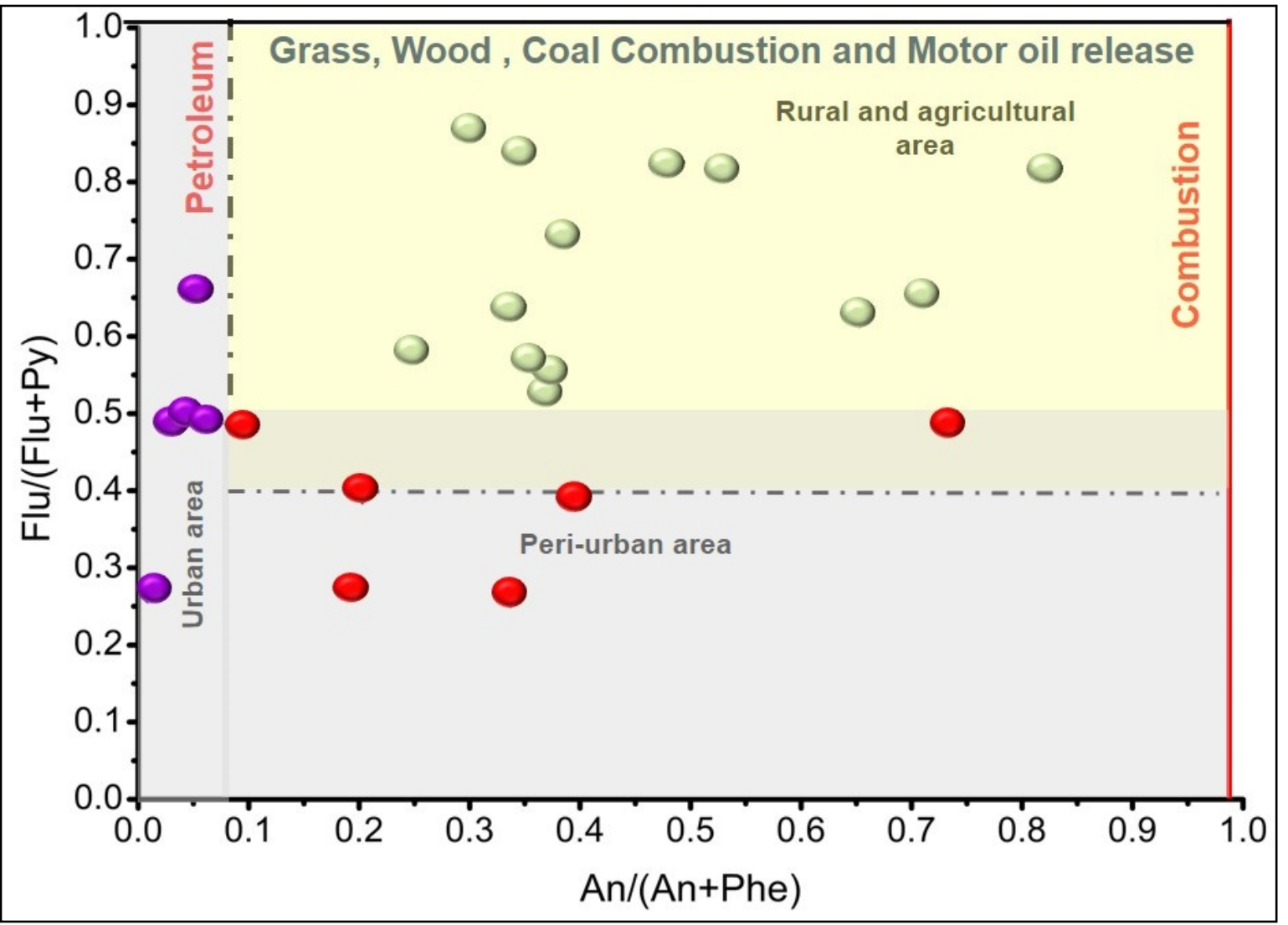

$43 \quad$ Fig. 5

44 
Distance (in $\mathrm{m}$ from target well)

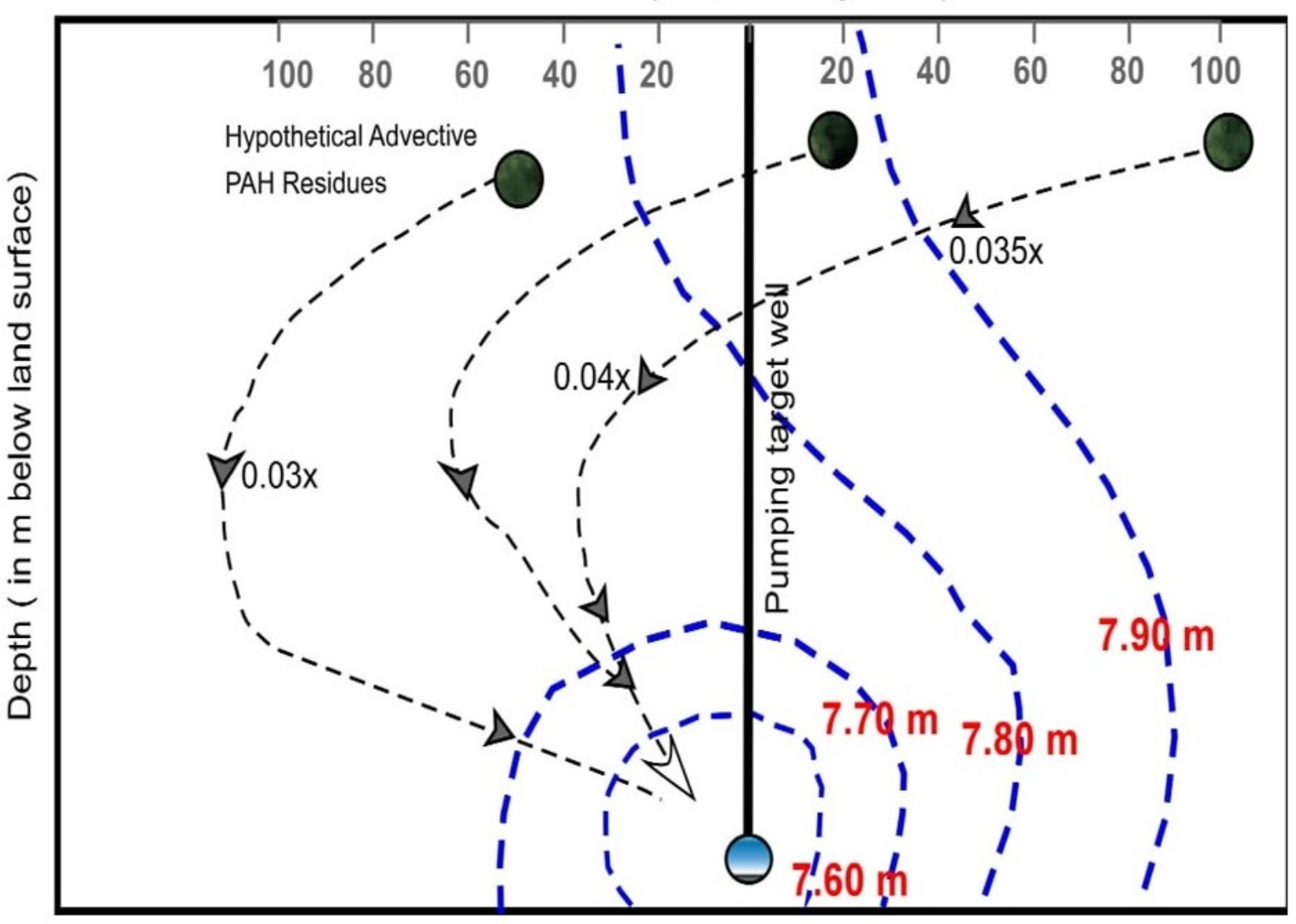

Fig. 6

47 
52 Figure 1S. Naphthalene concentration $(\mu \mathrm{g} / \mathrm{kg})$ adsorbed onto natural sediment having 53 dominant mineral quartz and kaolinite along with laboratory grade quartz and kaolinite 54

55

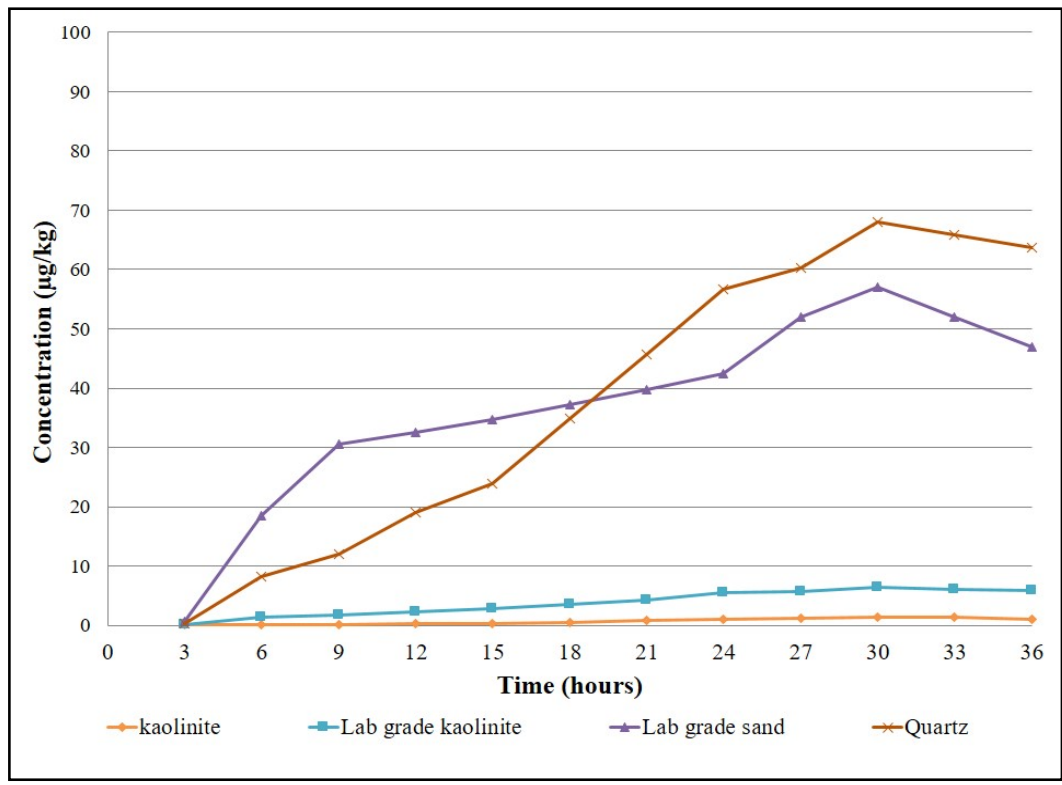

$56 \quad$ Fig.1S

57 Figure 2S Phenanthrene concentration $(\mu \mathrm{g} / \mathrm{kg})$ adsorbed onto natural sediment having dominant mineral quartz and kaolinite along with laboratory grade quartz and kaolinite

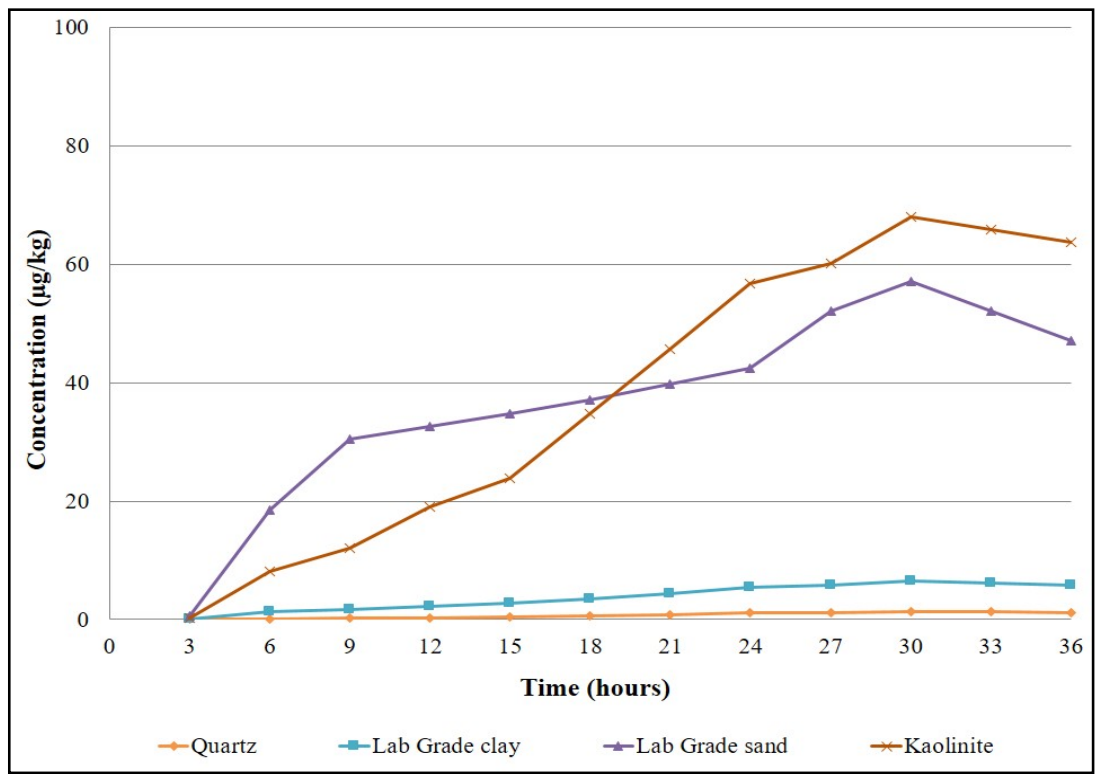


61 Figure 3S. Fluoranthene concentration $(\mu \mathrm{g} / \mathrm{kg})$ adsorbed onto natural sediment having dominant mineral quartz and kaolinite along with laboratory grade quartz and kaolinite

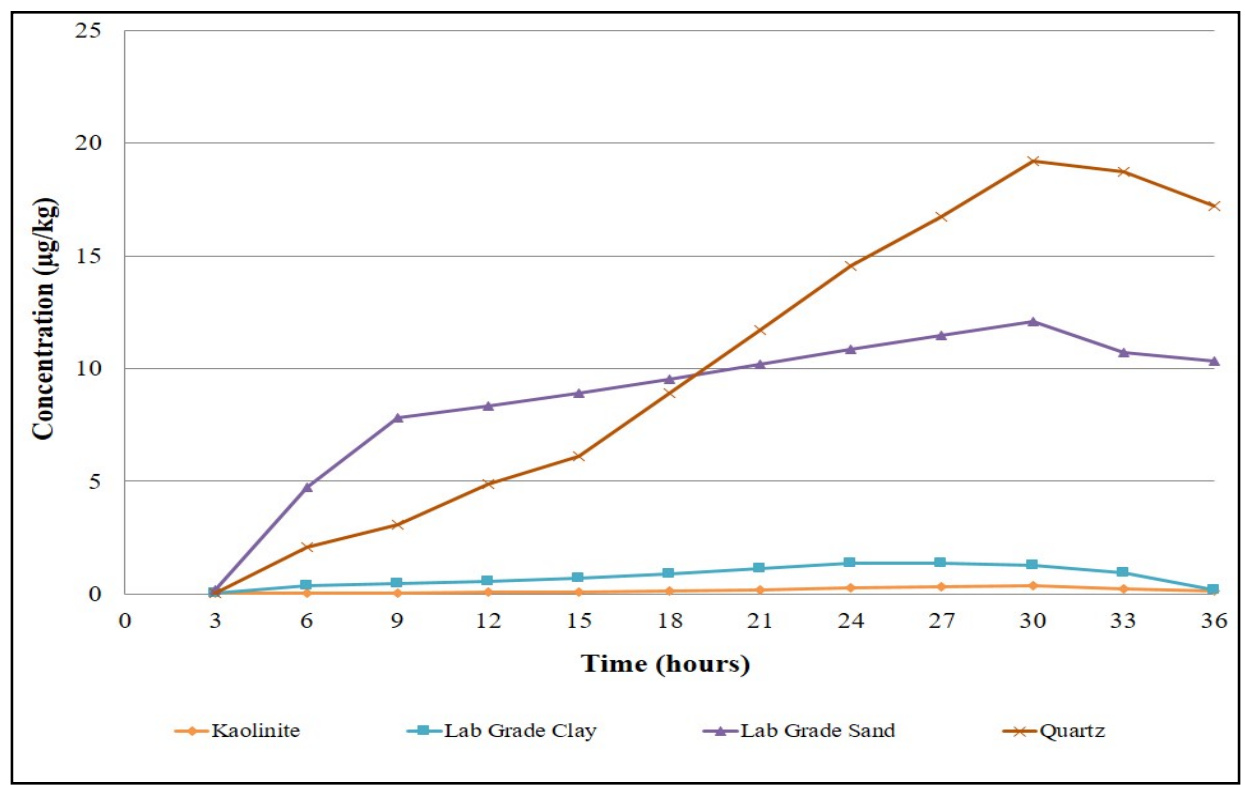

64

Fig.3S

65

Figure 4S. Hierarchical Cluster Analysis (HCA) for PAHs present in different land uses 66

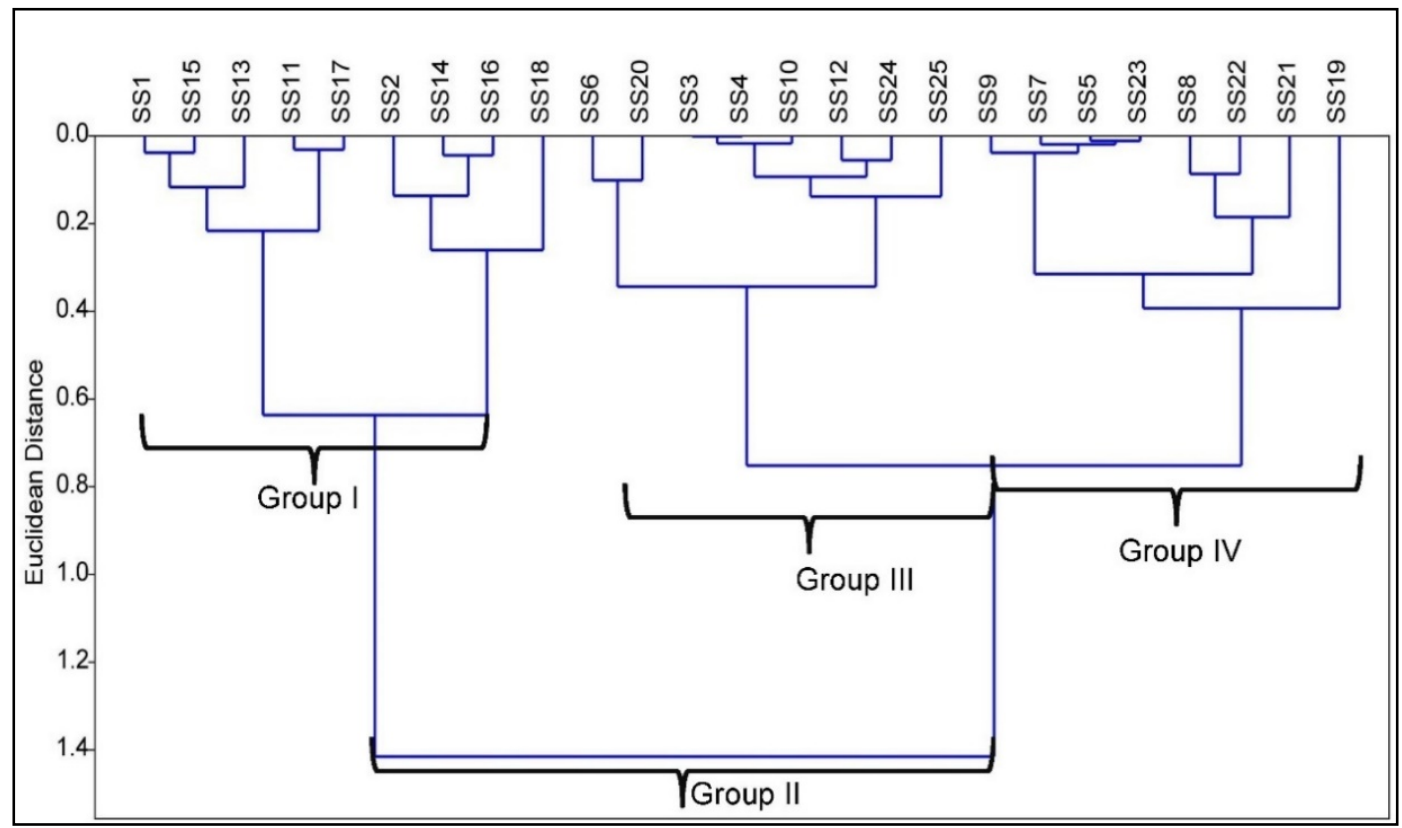

68 
70 Table 1S: Groundwater sampling locations across Western Bengal basin

\begin{tabular}{|c|c|c|c|c|c|c|c|c|c|c|c|}
\hline \multicolumn{3}{|c|}{ Murshidabad } & \multicolumn{3}{|c|}{ Nadia } & \multicolumn{3}{|c|}{ North 24 Parganas } & \multicolumn{3}{|c|}{ South 24 Parganas } \\
\hline Sample ID & Latitude & Longitude & Sample ID & Latitude & Longitude & Sample ID & Latitude & Longitude & Sample ID & Latitude & Longitude \\
\hline $\mathrm{S} 1$ & 24.2598 & 88.6592 & S89 & 23.7639 & 88.3789 & $\mathrm{~S} 154$ & 22.7219 & 88.4006 & S178 & 22.4867 & 88.3636 \\
\hline $\mathrm{S} 2$ & 24.2597 & 88.6590 & $\mathrm{~S} 90$ & 24.0329 & 88.7140 & $\mathrm{~S} 155$ & 22.774 & 88.3961 & S179 & 22.4878 & 88.3646 \\
\hline $\mathrm{S} 3$ & 23.9901 & 87.9140 & S91 & 24.0421 & 88.7105 & S156 & 22.8928 & 88.5535 & S180 & 22.4878 & 88.3646 \\
\hline S4 & 23.9912 & 87.9128 & $\mathrm{~S} 92$ & 23.5507 & 88.3827 & S157 & 22.5735 & 88.5016 & $\mathrm{~S} 181$ & 22.4879 & 88.3642 \\
\hline S5 & 24.1187 & 88.6566 & S93 & 23.5475 & 88.3887 & S158 & 23.1635 & 88.8907 & S182 & 22.4038 & 88.1504 \\
\hline S6 & 24.1131 & 88.6382 & S94 & 22.9932 & 88.5477 & S159 & 22.7361 & 88.535 & S183 & 22.1879 & 88.2254 \\
\hline S7 & 24.1150 & 88.6442 & S95 & 22.9931 & 88.5478 & $\mathrm{~S} 160$ & 22.7382 & 88.403 & S184 & 22.1871 & 88.2245 \\
\hline S8 & 24.1167 & 88.6506 & S96 & 22.9595 & 88.5661 & S161 & 22.7342 & 88.4029 & $\mathrm{~S} 185$ & 22.1879 & 88.2256 \\
\hline S9 & 24.1142 & 88.6458 & S97 & 22.9353 & 88.5415 & S162 & 22.5931 & 88.4895 & S186 & 22.1893 & 88.2266 \\
\hline S10 & 23.8511 & 88.2598 & S98 & 23.0277 & 88.5888 & S163 & 22.9253 & 88.7969 & S187 & 22.1843 & 88.2261 \\
\hline S11 & 23.8506 & 88.2562 & S99 & 23.0380 & 88.5144 & S164 & 22.9233 & 88.7891 & $\mathrm{~S} 188$ & 22.1864 & 88.2280 \\
\hline S12 & 23.8545 & 88.2524 & $\mathrm{~S} 100$ & 23.2906 & 88.3689 & S165 & 22.8083 & 88.5154 & S189 & 22.1832 & 88.2267 \\
\hline S13 & 23.8662 & 88.2485 & S101 & 23.2321 & 88.5233 & S166 & 22.8886 & 88.7404 & S190 & 22.1863 & 88.2272 \\
\hline S14 & 23.8227 & 88.2637 & $\mathrm{~S} 102$ & 23.2868 & 88.3590 & S167 & 22.8897 & 88.7376 & S191 & 22.3947 & 88.2042 \\
\hline S15 & 24.1586 & 88.6473 & $\mathrm{~S} 103$ & 23.6890 & 88.5292 & $\mathrm{~S} 168$ & 22.8886 & 88.7404 & S192 & 22.3912 & 88.2139 \\
\hline S16 & 24.1534 & 88.6468 & S104 & 23.6902 & 88.5306 & S169 & 22.8897 & 88.7376 & S193 & 22.3953 & 88.2046 \\
\hline S17 & 24.1587 & 88.6438 & S105 & 23.6912 & 88.5306 & $\mathrm{~S} 170$ & 23.0543 & 88.8071 & S194 & 22.3948 & 88.2042 \\
\hline S18 & 24.1548 & 88.6479 & S106 & 23.2327 & 88.4965 & S171 & 23.0572 & 88.7926 & S195 & 22.3949 & 88.2042 \\
\hline S19 & 23.9296 & 88.0470 & S107 & 23.2385 & 88.4590 & S172 & 22.8456 & 88.7442 & S196 & 22.4063 & 88.2186 \\
\hline $\mathrm{S} 20$ & 23.9282 & 88.0471 & $\mathrm{~S} 108$ & 23.3936 & 88.6581 & S173 & 22.8471 & 88.7501 & S197 & 22.4062 & 88.2187 \\
\hline $\mathrm{S} 21$ & 23.9453 & 88.0405 & S109 & 23.3904 & 88.6524 & S174 & 22.8487 & 88.7493 & S198 & 22.4060 & 88.2188 \\
\hline $\mathrm{S} 22$ & 23.9441 & 88.0405 & $\mathrm{~S} 110$ & 23.3415 & 88.4152 & S175 & 22.8369 & 88.6949 & S199 & 22.4060 & 88.2188 \\
\hline $\mathrm{S} 23$ & 24.1720 & 88.6056 & S111 & 23.3373 & 88.4190 & S176 & 22.8391 & 88.6964 & S200 & 22.4061 & 88.2193 \\
\hline $\mathrm{S} 24$ & 24.1723 & 88.6063 & $\mathrm{~S} 112$ & 23.3542 & 88.4235 & S177 & 22.8376 & 88.6965 & S201 & 22.4064 & 88.2196 \\
\hline $\mathrm{S} 25$ & 23.9435 & 88.0229 & S113 & 23.3538 & 88.4247 & & & & S202 & 22.4065 & 88.2195 \\
\hline $\mathrm{S} 26$ & 23.9433 & 88.0238 & S114 & 23.3552 & 88.4212 & & & & S203 & 22.4068 & 88.2192 \\
\hline S27 & 23.9199 & 88.0533 & S115 & 23.0232 & 88.5990 & & & & S204 & 22.4067 & 88.2193 \\
\hline $\mathrm{S} 28$ & 23.9193 & 88.0554 & S116 & 23.0233 & 88.6002 & & & & S205 & 22.4068 & 88.2193 \\
\hline S29 & 23.9171 & 88.0611 & S117 & 23.0053 & 88.6023 & & & & S206 & 22.4342 & 88.2916 \\
\hline $\mathrm{S} 30$ & 23.9299 & 88.0458 & S118 & 23.0092 & 88.6028 & & & & S207 & 22.4307 & 88.2997 \\
\hline
\end{tabular}




\begin{tabular}{|c|c|c|c|c|c|c|c|c|}
\hline S31 & 23.8963 & 88.4624 & S119 & 23.0124 & 88.6051 & S208 & 22.4332 & 88.2994 \\
\hline S32 & 24.1078 & 88.6361 & $\mathrm{~S} 120$ & 23.0133 & 88.6048 & S209 & 22.4358 & 88.3007 \\
\hline S33 & 24.1080 & 88.6367 & $\mathrm{~S} 121$ & 23.3656 & 88.3382 & $\mathrm{~S} 210$ & 22.4339 & 88.2979 \\
\hline S34 & 23.8988 & 87.9343 & $\mathrm{~S} 122$ & 23.2503 & 88.5389 & S211 & 22.4349 & 88.2983 \\
\hline S35 & 23.8986 & 87.9342 & $\mathrm{~S} 123$ & 23.2528 & 88.5396 & $\mathrm{~S} 212$ & 22.3881 & 88.2467 \\
\hline S36 & 24.0495 & 88.6330 & $\mathrm{~S} 124$ & 23.2549 & 88.5250 & $\mathrm{~S} 213$ & 22.4270 & 88.3020 \\
\hline S37 & 24.0658 & 88.6049 & $\mathrm{~S} 125$ & 23.2528 & 88.5225 & S214 & 22.4268 & 88.3068 \\
\hline S38 & 24.0712 & 88.6026 & S126 & 23.2525 & 88.5339 & $\mathrm{~S} 215$ & 22.4336 & 88.2977 \\
\hline S39 & 23.9625 & 87.9275 & $\mathrm{~S} 127$ & 22.9964 & 88.4909 & S216 & 22.3964 & 88.2081 \\
\hline $\mathrm{S} 40$ & 23.9614 & 87.9286 & $\mathrm{~S} 128$ & 22.9826 & 88.4904 & S217 & 22.3995 & 88.2083 \\
\hline S41 & 23.9724 & 87.9281 & S129 & 23.7691 & 88.2672 & S218 & 22.3948 & 88.2042 \\
\hline S42 & 23.9192 & 88.3620 & $\mathrm{~S} 130$ & 23.6210 & 88.3137 & S219 & 22.3948 & 88.2068 \\
\hline S43 & 24.0063 & 88.0241 & $\mathrm{~S} 131$ & 23.7682 & 88.2666 & S220 & 22.4339 & 88.2979 \\
\hline S44 & 23.7708 & 88.2194 & S132 & 23.6202 & 88.3143 & S221 & 22.4336 & 88.2977 \\
\hline S45 & 24.0420 & 88.5520 & $\mathrm{~S} 133$ & 23.7707 & 88.2611 & S222 & 22.3881 & 88.2467 \\
\hline S46 & 24.0428 & 88.5500 & $\mathrm{~S} 134$ & 23.7696 & 88.2587 & S223 & 22.4270 & 88.3020 \\
\hline S47 & 24.0429 & 88.5488 & S135 & 23.6219 & 88.3129 & S224 & 22.4268 & 88.3068 \\
\hline S48 & 24.0420 & 88.5518 & S136 & 23.7671 & 88.2590 & $\mathrm{~S} 225$ & 22.4357 & 88.2999 \\
\hline S49 & 24.0431 & 88.5523 & $\mathrm{~S} 137$ & 23.6151 & 88.3265 & S226 & 22.4351 & 88.3004 \\
\hline S50 & 24.0097 & 88.5350 & S138 & 23.7699 & 88.2649 & S227 & 22.4349 & 88.2983 \\
\hline S51 & 24.0103 & 88.5327 & S139 & 23.6384 & 88.2657 & S228 & 22.4332 & 88.2994 \\
\hline S52 & 24.0089 & 88.5330 & $\mathrm{~S} 140$ & 23.6184 & 88.3121 & S229 & 22.4339 & 88.2979 \\
\hline S53 & 23.9355 & 88.1099 & $\mathrm{~S} 141$ & 23.7680 & 88.2583 & $\mathrm{~S} 230$ & 22.4336 & 88.2977 \\
\hline S54 & 23.9321 & 88.1085 & $\mathrm{~S} 142$ & 23.6315 & 88.2609 & $\mathrm{~S} 231$ & 22.3881 & 88.2467 \\
\hline S55 & 23.9301 & 88.1063 & $\mathrm{~S} 143$ & 23.7880 & 88.2505 & $\mathrm{~S} 232$ & 22.4270 & 88.3020 \\
\hline S56 & 23.9277 & 88.1068 & S144 & 23.7877 & 88.2508 & S233 & 22.4307 & 88.2997 \\
\hline S57 & 23.9323 & 88.1069 & $\mathrm{~S} 145$ & 23.5933 & 88.3415 & $\mathrm{~S} 234$ & 22.4268 & 88.3068 \\
\hline S58 & 24.0312 & 87.8844 & S146 & 23.5871 & 88.3353 & $\mathrm{~S} 235$ & 22.4336 & 88.2977 \\
\hline S59 & 24.0077 & 88.4952 & S147 & 23.5974 & 88.3474 & & & \\
\hline S60 & 23.8967 & 87.9282 & $\mathrm{~S} 148$ & 23.7580 & 88.3100 & & & \\
\hline S61 & 23.8914 & 87.9151 & S149 & 23.7596 & 88.3102 & & & \\
\hline S62 & 23.8913 & 87.9143 & $\mathrm{~S} 150$ & 23.5325 & 88.4034 & & & \\
\hline S63 & 24.0848 & 88.0711 & S151 & 23.5344 & 88.4013 & & & \\
\hline S64 & 23.8636 & 88.4632 & $\mathrm{~S} 152$ & 23.6892 & 88.3030 & & & \\
\hline
\end{tabular}




\begin{tabular}{llllll}
\hline S65 & 23.8630 & 88.4633 & $\mathrm{~S} 153$ & 23.6885 & 88.2997 \\
S66 & 23.9530 & 88.0752 & & & \\
S67 & 23.9534 & 88.0722 & & \\
S68 & 23.8214 & 88.4240 & & \\
S69 & 24.0914 & 88.6283 & & \\
S70 & 24.0907 & 88.6269 & & \\
S71 & 24.0928 & 88.6226 & & \\
S72 & 24.0931 & 88.6217 & & \\
S73 & 23.8211 & 88.4244 & & \\
S74 & 23.8211 & 88.4244 & & \\
S75 & 24.0949 & 88.6217 & & \\
S76 & 23.8183 & 88.4231 & & \\
S77 & 23.8183 & 88.4231 & & \\
S78 & 23.8195 & 88.4242 & & \\
S79 & 23.8195 & 88.4242 & & \\
S80 & 23.8216 & 88.4233 & & \\
S81 & 23.8216 & 88.4233 & & \\
S82 & 24.0926 & 88.6250 & & \\
S83 & 24.0943 & 88.6227 & & \\
S84 & 23.8184 & 88.4230 & & \\
S85 & 23.8149 & 88.4214 & & \\
S86 & 23.9531 & 88.2154 & & \\
S87 & 23.9531 & 88.2151 & & \\
S88 & 24.3408 & 88.3023 & & \\
& & & & \\
\end{tabular}


Table 2S: River water sampling locations across Western Bengal basin

\begin{tabular}{crr}
\hline Sample ID & Latitude & \multicolumn{1}{c}{ Longitude } \\
\hline WBB1 & 24.75 & 87.74 \\
WBB2 & 24.63 & 87.97 \\
WBB3 & 24.59 & 88.02 \\
WBB4 & 24.53 & 88.06 \\
WBB5 & 24.44 & 88.09 \\
WBB6 & 24.31 & 88.18 \\
WBB7 & 24.19 & 88.24 \\
WBB8 & 24.10 & 88.23 \\
WBB9 & 23.94 & 88.23 \\
WBB10 & 23.84 & 88.23 \\
WBB11 & 23.68 & 88.15 \\
WBB12 & 23.56 & 88.33 \\
WBB13 & 23.49 & 88.38 \\
WBB14 & 23.43 & 88.32 \\
WBB15 & 23.36 & 88.34 \\
WBB16 & 23.29 & 88.36 \\
WBB17 & 23.23 & 88.46 \\
WBB18 & 23.17 & 88.46 \\
WBB19 & 23.06 & 88.49 \\
WBB20 & 23.01 & 88.45 \\
WBB21 & 22.92 & 88.39 \\
WBB22 & 22.85 & 88.37 \\
WBB23 & 22.76 & 88.36 \\
WBB24 & 22.67 & 88.36 \\
WBB25 & 22.62 & 88.30 \\
WBB26 & 22.57 & 88.24 \\
WBB27 & 22.53 & 88.16 \\
WBB28 & 22.47 & 88.12 \\
WBB29 & 22.40 & 88.09 \\
WBB30 & 22.32 & 88.09 \\
WBB31 & 88.07 \\
WBB32 & 22.26 & 88.17 \\
\hline
\end{tabular}


79 Table 3S: Detailed information on mineralogical characteristics, $\mathrm{pH}$ and average organic 80 carbon content $(\mathrm{mg} / \mathrm{kg})$ for 25 sediment samples

\begin{tabular}{|c|c|c|c|}
\hline Sampling site & Mineral characterization & $\mathbf{p H}$ & $\begin{array}{c}\text { Average } \\
\text { organic carbon } \\
\text { content }\end{array}$ \\
\hline SS1 & Quartz, Silica & 8.1 & 0.92 \\
\hline $\mathrm{SS} 2$ & Quartz, Silica & 7.9 & 1.93 \\
\hline SS3 & Quartz, Feldspar & 8.0 & 2.18 \\
\hline SS4 & Quartz, Silica & 7.3 & 0.60 \\
\hline SS5 & Illite, Smectite & 7.5 & 3.21 \\
\hline SS6 & Calcite & 7.2 & 2.10 \\
\hline SS7 & Muscovite & 7.0 & 2.13 \\
\hline SS8 & Muscovite & 6.9 & 2.09 \\
\hline SS9 & Kaolinite, Kaolinite & 6.7 & 1.69 \\
\hline SS10 & Albite, Muscovite & 6.5 & 1.51 \\
\hline SS11 & Quartz, Silica & 7.3 & 1.19 \\
\hline $\mathrm{SS} 12$ & Muscovite, Illite & 8.1 & 0.93 \\
\hline SS 13 & Orthoclase & 6.9 & 1.21 \\
\hline SS14 & Sanidine & 6.8 & 1.15 \\
\hline SS15 & Orthoclase, Berlinite & 6.8 & 1.75 \\
\hline SS16 & Anorthite & 6.7 & 1.69 \\
\hline SS 17 & Calcite & 7.6 & 0.97 \\
\hline SS 18 & Muscovite, Kaolinite & 7.6 & 0.91 \\
\hline SS19 & Quartz, Silica & 7.5 & 1.51 \\
\hline SS20 & Quartz, Feldspar & 6.4 & 2.11 \\
\hline SS21 & Kaolinite, Orthoclase & 7.3 & 2.05 \\
\hline SS22 & Muscovite, Illite & 7.3 & 0.67 \\
\hline $\mathrm{SS} 23$ & Albite, Muscovite & 7.2 & 0.61 \\
\hline SS24 & Anorthite, Illite & 7.1 & 1.21 \\
\hline $\mathrm{SS} 25$ & Muscovite, Illite, Kaolinite & 7.1 & 1.15 \\
\hline
\end{tabular}

81

82

83

84 
Table 4S: Minimum detection limit and extraction recoveries for the polycyclic aromatic

87 Hydrocarbons (PAHs) in water samples

\begin{tabular}{|c|c|c|c|c|c|c|c|}
\hline Compounds & $\begin{array}{c}\text { Detecti } \\
\text { on } \\
\text { limit } \\
(\mu \mathrm{g} / \mathrm{L})\end{array}$ & $\begin{array}{l}\text { Internal } \\
\text { standard } \\
\text { injected }\end{array}$ & $\begin{array}{c}\text { Internal } \\
\text { standard } \\
\text { recovered }\end{array}$ & $\begin{array}{l}\text { Reco } \\
\text { very } \\
(\%)\end{array}$ & $\begin{array}{c}\text { Internal } \\
\text { standard } \\
\text { injected }\end{array}$ & $\begin{array}{c}\text { Internal } \\
\text { standard } \\
\text { recovered }\end{array}$ & $\begin{array}{c}\text { Recov } \\
\text { ery } \\
(\%)\end{array}$ \\
\hline Naphthalene & 0.3 & 0.5 & 0.32 & 64 & 1 & 0.89 & 66 \\
\hline Acenaphthylene & 0.5 & 0.5 & 0.39 & 78 & 1 & 0.91 & 77 \\
\hline Acenaphthene & 0.5 & 0.5 & 0.41 & 82 & 1 & 0.93 & 83 \\
\hline Fluorene & 0.5 & 0.5 & 0.46 & 92 & 1 & 0.98 & 96 \\
\hline Phenanthrene & 0.5 & 0.5 & 0.43 & 86 & 1 & 0.95 & 88 \\
\hline Anthracene & 0.3 & 0.5 & 0.32 & 64 & 1 & 0.84 & 50 \\
\hline Fluoranthene & 0.3 & 0.5 & 0.39 & 78 & 1 & 0.91 & 77 \\
\hline Pyrene & 0.2 & 0.5 & 0.33 & 66 & 1 & 0.85 & 55 \\
\hline $\begin{array}{c}\text { Benz(a)anthrace } \\
\text { ne } \\
\end{array}$ & 0.2 & 0.5 & 0.42 & 84 & 1 & 0.82 & 82 \\
\hline Chrysene & 0.2 & 0.5 & 0.39 & 78 & 1 & 0.91 & 77 \\
\hline $\begin{array}{c}\text { Benzo(b) } \\
\text { fluoranthene }\end{array}$ & 0.2 & 0.5 & 0.41 & 82 & 1 & 0.93 & 83 \\
\hline $\begin{array}{c}\text { Benzo(k) } \\
\text { fluoranthene }\end{array}$ & 0.2 & 0.5 & 0.37 & 74 & 1 & 0.89 & 70 \\
\hline Benzo(a) pyrene & 0.1 & 0.5 & 0.32 & 64 & 1 & 0.84 & 50 \\
\hline $\begin{array}{c}\text { d-Perylene } \\
\text { (Istd)* }\end{array}$ & 0.1 & 0.5 & 0.42 & 84 & 1 & 0.94 & 86 \\
\hline Perylene & 1.0 & 0.5 & 0.4 & 80 & 1 & 0.92 & 80 \\
\hline $\begin{array}{c}\text { Indeno(1,2,3) } \\
\text { pyrene }\end{array}$ & 0.2 & 0.5 & 0.29 & 58 & 1 & 0.81 & 34 \\
\hline $\begin{array}{c}\text { Dibenzo(a,h) } \\
\text { anthracene }\end{array}$ & 0.9 & 0.5 & 0.39 & 78 & 1 & 0.91 & 77 \\
\hline $\begin{array}{c}\text { Benzo(g,h,i) } \\
\text { perylene }\end{array}$ & 0.9 & 0.5 & 0.36 & 72 & 1 & 0.89 & 69 \\
\hline $\begin{array}{l}\text { 1,3-dimethyl } \\
\text { naphthalene }\end{array}$ & 0.25 & 0.5 & 0.32 & 64 & 1 & 0.69 & 69 \\
\hline $\begin{array}{l}\text { 1-methyl } \\
\text { naphthalene }\end{array}$ & 0.4 & 0.5 & 0.47 & 94 & 1 & 0.75 & 75 \\
\hline $\begin{array}{l}\text { 2-methyl } \\
\text { naphthalene }\end{array}$ & 0.39 & 0.5 & 0.45 & 90 & 1 & 0.74 & 74 \\
\hline $\begin{array}{l}\text { 2,6-dimethyl } \\
\text { naphthalene }\end{array}$ & 0.42 & 0.5 & 0.45 & 90 & 1 & 0.89 & 89 \\
\hline
\end{tabular}


91 Table 5S: Minimum detection limit and extraction recoveries for the PAHs in sediment

samples

\begin{tabular}{|c|c|c|c|c|c|c|c|}
\hline Compounds & $\begin{array}{c}\text { Detectio } \\
\text { n limit } \\
(\mu \mathrm{g} / \mathrm{kg})\end{array}$ & $\begin{array}{c}\text { Internal } \\
\text { standard } \\
\text { injected }\end{array}$ & $\begin{array}{c}\text { Internal } \\
\text { standard } \\
\text { recovered }\end{array}$ & $\begin{array}{c}\text { Reco } \\
\text { very } \\
(\%)\end{array}$ & $\begin{array}{c}\text { Internal } \\
\text { standard } \\
\text { injected }\end{array}$ & $\begin{array}{c}\text { Internal } \\
\text { standard } \\
\text { recovered }\end{array}$ & $\begin{array}{c}\text { Recovery } \\
(\%)\end{array}$ \\
\hline Napthalene & 0.3 & 0.5 & 0.34 & 68 & 1 & 0.67 & 66 \\
\hline Acenaphthylene & 0.5 & 0.5 & 0.41 & 82 & 1 & 0.85 & 77 \\
\hline Acenaphthene & 0.5 & 0.5 & 0.43 & 86 & 1 & 0.87 & 83 \\
\hline Fluorene & 0.5 & 0.5 & 0.48 & 96 & 1 & 0.92 & 96 \\
\hline Phenanthrene & 0.5 & 0.5 & 0.45 & 90 & 1 & 0.89 & 88 \\
\hline Anthracene & 0.3 & 0.5 & 0.34 & 68 & 1 & 0.68 & 50 \\
\hline Fluoranthene & 0.3 & 0.5 & 0.41 & 82 & 1 & 0.85 & 77 \\
\hline $\begin{array}{c}\text { Pyrene } \\
\text { Benz(a)anthrace }\end{array}$ & 0.2 & 0.5 & 0.35 & 70 & 1 & 0.79 & 55 \\
\hline ne & 0.2 & 0.5 & 0.44 & 88 & 1 & 0.86 & 82 \\
\hline $\begin{array}{c}\text { Chrysene } \\
\text { nenzo(b)fluora }\end{array}$ & 0.2 & 0.5 & 0.41 & 82 & 1 & 0.85 & 77 \\
\hline $\begin{array}{c}\text { Benzo(k)fluora } \\
\text { nthene }\end{array}$ & 0.2 & 0.5 & 0.39 & 78 & 1 & 0.76 & 70 \\
\hline Benzo(a)pyrene & 0.1 & 0.5 & 0.34 & 68 & 1 & 0.65 & 50 \\
\hline $\begin{array}{c}\text { d-Perylene } \\
\text { (Istd)* }\end{array}$ & 0.1 & 0.5 & 0.44 & 88 & 1 & 0.88 & 86 \\
\hline Perylene & 1.0 & 0.5 & 0.42 & 84 & 1 & 0.86 & 80 \\
\hline $\begin{array}{c}\text { Indeno(1,2,3)py } \\
\text { rene }\end{array}$ & 0.2 & 0.5 & 0.31 & 62 & 1 & 0.65 & 34 \\
\hline $\begin{array}{c}\text { Dibenzo(a,h)ant } \\
\text { hracene }\end{array}$ & 0.9 & 0.5 & 0.41 & 82 & 1 & 0.85 & 77 \\
\hline $\begin{array}{c}\text { Benzo(g,h,i)per } \\
\text { ylene }\end{array}$ & 0.9 & 0.5 & 0.38 & 76 & 1 & 0.79 & 69 \\
\hline $\begin{array}{c}\text { 1,3-dimethyl } \\
\text { naphthalene }\end{array}$ & 0.25 & 0.5 & 0.29 & 58 & 1 & 0.61 & 61 \\
\hline $\begin{array}{c}\text { 1-methyl } \\
\text { naphthalene }\end{array}$ & 0.4 & 0.5 & 0.44 & 88 & 1 & 0.74 & 74 \\
\hline $\begin{array}{c}\text { 2-methyl } \\
\text { naphthalene }\end{array}$ & 0.39 & 0.5 & 0.41 & 82 & 1 & 0.69 & 69 \\
\hline $\begin{array}{c}\text { 2,6-dimethyl } \\
\text { naphthalene }\end{array}$ & 0.42 & 0.5 & 0.43 & 86 & 1 & 0.83 & 83 \\
\hline
\end{tabular}

93 
96 Table 6S: Polyaromatic Hydrocarbons (PAHs) concentration $(\mu \mathrm{g} / \mathrm{L})$ in river water samples for 97 four districts of Western Bengal basin

\begin{tabular}{cccccccccccccc}
\hline Components & \multicolumn{3}{c}{ Murshidabad } & \multicolumn{3}{c}{ Nadia } & \multicolumn{4}{c}{ North 24 Parganas } & \multicolumn{3}{c}{ South 24 Parganas } \\
& Med & Min & Max & Med & Min & Ma & Med & Min & Max & Me & Min & Max \\
\hline Naphthalene & 7.41 & 5.80 & 9.01 & 23.13 & 12.21 & 34.0 & 4.30 & 2.60 & 6.00 & 8.33 & 1.34 & 15.32 \\
Phenanthrene & 5.83 & 4.90 & 6.76 & 4.84 & 1.54 & 8.14 & 5.71 & 3.86 & 7.57 & 5.67 & 2.99 & 8.35 \\
Anthracene & 3.10 & 3.06 & 3.14 & 1.16 & 0.56 & 1.76 & 2.14 & 1.03 & 3.25 & 0.33 & 0.11 & 0.55 \\
Fluoranthene & 3.65 & 3.57 & 3.74 & 3.90 & 2.91 & 4.90 & 7.22 & 5.38 & 9.07 & 1.70 & 1.16 & 2.24 \\
Chrysene & 0.36 & 0.07 & 0.65 & 0.12 & 0.07 & 0.17 & 0.22 & 0.14 & 0.31 & 0.09 & 0.04 & 0.13 \\
Pyrene & 0.20 & 0.09 & 0.30 & 0.10 & 0.10 & 0.10 & 0.01 & 0.00 & 0.01 & 0.16 & 0.10 & 0.21 \\
1,3-dimethyl naphthalene & 4.60 & 3.58 & 3.70 & 4.96 & 3.16 & 6.75 & 2.18 & 1.86 & 2.50 & 1.59 & 1.02 & 2.16 \\
1-methyl naphthalene & 4.60 & 4.56 & 4.63 & 1.20 & 0.93 & 1.48 & 2.23 & 1.71 & 2.74 & 1.44 & 1.22 & 1.66 \\
2-methyl naphthalene & 3.50 & 3.43 & 3.57 & 3.80 & 2.61 & 5.00 & 5.04 & 0.83 & 9.24 & 0.89 & 0.44 & 1.33 \\
2,6-dimethyl naphthalene & 3.87 & 3.63 & 4.11 & 2.49 & 1.31 & 3.66 & 4.61 & 2.43 & 6.78 & 0.71 & 0.53 & 0.90 \\
\hline
\end{tabular}

98

99 Table 7S: Polyaromatic Hydrocarbons (PAHs) $(\mu \mathrm{g} / \mathrm{kg})$ concentration in sediment samples 100 collected across the study area

\begin{tabular}{ccccccccccccccc}
\hline \multirow{2}{*}{ Components } & \multicolumn{3}{c}{ Murshidabad } & \multicolumn{4}{c}{ Nadia } & \multicolumn{4}{c}{ North 24 Parganas } & \multicolumn{3}{c}{ South 24 Parganas } \\
& Mean & Min & Max & Mean & Min & Max & Mean & Min & Max & Mean & Min & Max \\
\hline Naphthalene & 3.38 & 2.64 & 4.11 & 10.55 & 5.57 & 15.53 & 1.96 & 1.19 & 2.74 & 3.80 & 0.61 & 6.99 \\
Phenanthrene & 2.66 & 2.24 & 3.08 & 2.21 & 0.70 & 3.71 & 2.61 & 1.76 & 3.45 & 2.59 & 1.36 & 3.81 \\
Anthracene & 1.41 & 1.40 & 1.43 & 0.53 & 0.25 & 0.80 & 0.98 & 0.47 & 1.48 & 0.15 & 0.05 & 0.25 \\
Fluoranthene & 1.67 & 1.63 & 1.70 & 1.78 & 1.33 & 2.24 & 3.29 & 2.45 & 4.14 & 0.78 & 0.53 & 1.02 \\
Chrysene & 0.16 & 0.03 & 0.30 & 0.06 & 0.03 & 0.08 & 0.10 & 0.06 & 0.14 & 0.04 & 0.02 & 0.06 \\
Benzo(a)anthracene & 1.86 & 1.69 & 2.03 & 2.82 & 2.63 & 3.01 & 1.51 & 1.09 & 1.92 & 3.18 & 3.09 & 3.26 \\
Pyrene & 0.09 & 0.04 & 0.14 & 0.05 & 0.04 & 0.05 & 0.00 & 0.00 & 0.00 & 0.07 & 0.05 & 0.10 \\
1,3-dimethyl naphthalene & 1.66 & 1.63 & 1.69 & 2.26 & 1.44 & 3.08 & 0.99 & 0.85 & 1.14 & 0.73 & 0.47 & 0.99 \\
1-methyl naphthalene & 2.10 & 2.08 & 2.11 & 0.55 & 0.42 & 0.68 & 1.02 & 0.78 & 1.25 & 0.66 & 0.56 & 0.76 \\
2-methyl naphthalene & 1.60 & 1.56 & 1.63 & 1.73 & 1.19 & 2.28 & 2.30 & 0.38 & 4.22 & 0.40 & 0.20 & 0.61 \\
2,6-dimethyl naphthalene & 1.77 & 1.66 & 1.87 & 1.14 & 0.60 & 1.67 & 2.10 & 1.11 & 3.09 & 0.33 & 0.24 & 0.41 \\
\hline
\end{tabular}

101

102 
104 Table 8S: Isotherm parameters for Langmuir and Freundlich models for naphthalene

\begin{tabular}{llllll}
\hline \multirow{2}{*}{$\begin{array}{lllll}\text { Isotherm Model } \\
\text { For naphthalene }\end{array}$} & $\begin{array}{l}\text { Estimated } \\
\text { isotherm } \\
\text { parameters }\end{array}$ & Quartz & Kaolinite & $\begin{array}{c}\text { Laboratory } \\
\text { grade quartz }\end{array}$ & $\begin{array}{l}\text { Laboratory } \\
\text { grade } \\
\text { kaolinite }\end{array}$ \\
\cline { 3 - 6 } & $\mathrm{q}_{\max }(\mathrm{mg} / \mathrm{g})$ & 25.95 & 16.51 & 22.41 & 18.68 \\
Langmuir & $\mathrm{b}$ & 0.39 & 0.00 & 0.05 & 0.01 \\
& $\mathrm{R}^{2}$ & 0.93 & 0.91 & 0.98 & 0.98 \\
\cline { 2 - 6 } & $\mathrm{n}$ & 0.68 & 0.40 & 0.77 & 0.28 \\
Freundlich & $\mathrm{K}_{\mathrm{f}}$ & 9.67 & 2.43 & 8.60 & 11.53 \\
& $\mathrm{R}^{2}$ & 0.91 & 0.89 & 0.98 & 0.97 \\
\hline
\end{tabular}

Table 9S: Isotherm parameters for Langmuir and Freundlich models for fluoranthene

\begin{tabular}{cccccc}
\hline $\begin{array}{c}\text { Isotherm Model for } \\
\text { fluoranthene }\end{array}$ & Estimated isotherm & \multicolumn{4}{c}{ Estimated isotherm parameters } \\
\cline { 3 - 6 } & parameters & Quartz & Kaolinite & $\begin{array}{c}\text { Laboratory } \\
\text { grade } \\
\text { quartz }\end{array}$ & $\begin{array}{c}\text { Laboratory } \\
\text { grade kaolinite }\end{array}$ \\
\hline Langmuir & $\mathrm{q}_{\max }(\mathrm{mg} / \mathrm{g})$ & 17.06 & 11.51 & 17.41 & 12.68 \\
& $\mathrm{~b}$ & 1.63 & 0.02 & 0.21 & 0.02 \\
& $\mathrm{R}^{2}$ & 0.95 & 0.94 & 0.96 & 0.97 \\
\hline Freundlich & $\mathrm{n}$ & 0.30 & 0.65 & 0.50 & 0.74 \\
& $\mathrm{~K}_{\mathrm{f}}$ & 8.54 & 81.30 & 14.47 & 10.40 \\
& $\mathrm{R}^{2}$ & 0.91 & 0.89 & 0.92 & 0.93 \\
\hline
\end{tabular}


Table 10S: Isotherm parameters for Langmuir and Freundlich models for phenanthrene

\begin{tabular}{cccccc}
\hline \multirow{2}{*}{$\begin{array}{c}\text { Isotherm Model for } \\
\text { phenanthrene }\end{array}$} & $\begin{array}{c}\text { Estimated } \\
\text { isotherm } \\
\text { parameters }\end{array}$ & Quartz & Kaolinite & $\begin{array}{c}\text { Laboratory } \\
\text { grade quartz }\end{array}$ & $\begin{array}{c}\text { Laboratory } \\
\text { grade } \\
\text { kaolinite }\end{array}$ \\
\cline { 3 - 6 } & $\mathrm{q}_{\max }(\mathrm{mg} / \mathrm{g})$ & 23.89 & 27.67 & 22.57 & 13.84 \\
Langmuir & $\mathrm{b}$ & 0.80 & 0.008 & 0.10 & 0.02 \\
& $\mathrm{R}^{2}$ & 0.99 & 0.95 & 0.99 & 0.98 \\
\cline { 2 - 6 } & $\mathrm{n}$ & 0.84 & 0.24 & 0.83 & 0.34 \\
& $\mathrm{~K}_{\mathrm{f}}$ & 9.10 & 81.86 & 15.04 & 10.96 \\
$\mathrm{R}^{2}$ & 0.91 & 0.87 & 0.97 & 0.96 \\
\hline
\end{tabular}


Table 11S: Physical properties of collected groundwater samples across the Western Bengal basin

\begin{tabular}{|c|c|c|c|c|c|c|c|c|c|c|c|c|c|c|c|}
\hline $\begin{array}{l}\text { Sample } \\
\text { Name }\end{array}$ & pH & TDS & Hardness & $\begin{array}{l}\text { Sample } \\
\text { Name }\end{array}$ & pH & TDS & Hardness & $\begin{array}{l}\text { Sample } \\
\text { Name }\end{array}$ & pH & TDS & Hardness & $\begin{array}{l}\text { Sample } \\
\text { Name }\end{array}$ & pH & TDS & Hardness \\
\hline & 7.1 & & & & & & & & & & & & & & \\
\hline S1 & 5 & 405 & 107 & S26 & 8 & 722 & 112 & S51 & 8.38 & 1924 & 104 & S76 & 7.4 & 332 & 120 \\
\hline S2 & 7.9 & 586 & 120 & S27 & 8.2 & 794 & 116 & S52 & 7 & 593 & 108 & S77 & 7.8 & 317 & 120 \\
\hline S3 & 8.1 & 624 & 120 & S28 & 8 & 1532 & 120 & S53 & 8 & 587 & 100 & $\mathrm{~S} 78$ & 6.9 & 294 & 120 \\
\hline S4 & 7.9 & 562 & 120 & S29 & 8.1 & 836 & 120 & S54 & 7 & 486 & 120 & S79 & 6.9 & 295 & 126 \\
\hline S5 & 7.9 & 592 & 116 & S30 & 8 & 624 & 116 & S55 & 7 & 575 & 108 & S80 & 8.3 & 405 & 120 \\
\hline S6 & 7.9 & 624 & 120 & S31 & 8 & 756 & 116 & S56 & 7 & 611 & 100 & S81 & 7.5 & 408 & 120 \\
\hline S7 & 7.8 & 654 & 116 & S32 & 8 & 892 & 120 & S57 & 7.5 & 632 & 104 & S82 & 8.3 & 627 & 120 \\
\hline S8 & 7.5 & 323 & 116 & S33 & 8.1 & 884 & 112 & S58 & 7.5 & 472 & 120 & S83 & 8.3 & 388 & 120 \\
\hline S9 & 7 & 427 & 100 & S34 & 8.1 & 698 & 112 & S59 & 8.5 & 561 & 120 & S84 & 6.8 & 299 & 120 \\
\hline S10 & 7.7 & 377 & 116 & S35 & 7.8 & 702 & 112 & S60 & 7.5 & 566 & 120 & S85 & 6.9 & 299 & 112 \\
\hline S11 & 7.9 & 390 & 120 & S36 & 8.1 & 712 & 112 & S61 & 7.5 & 664 & 120 & S86 & 7.2 & 299 & 112 \\
\hline $\mathrm{S} 12$ & 7.0 & 764 & 104 & S37 & 8.1 & 748 & 116 & S62 & 7.5 & 913 & 100 & S87 & 6.9 & 299 & 112 \\
\hline S13 & 7.5 & 611 & 112 & S38 & 8.2 & 740 & 120 & S63 & 8 & 838 & 120 & S88 & 8.1 & 594 & 112 \\
\hline S14 & 7.5 & 661 & 120 & S39 & 8.2 & 768 & 120 & S64 & 7 & 715 & 120 & S89 & 7.9 & 542 & 116 \\
\hline S15 & 8.3 & 650 & 116 & $\mathrm{~S} 40$ & 8 & 714 & 108 & S65 & 7 & 560 & 104 & S90 & 8 & 598 & 112 \\
\hline S16 & 8 & 564 & 120 & S41 & 8.2 & 734 & 120 & S66 & 7.5 & 464 & 100 & S91 & 8 & 598 & 116 \\
\hline S17 & 6.6 & 47 & 12 & S42 & 8.1 & 728 & 120 & S67 & 7.5 & 464 & 100 & S92 & 8.08 & 500 & 100 \\
\hline S18 & 7.9 & 620 & 120 & S43 & 8.1 & 700 & 112 & S68 & 7.5 & 563 & 120 & S93 & 8.5 & 688 & 100 \\
\hline S19 & 7.9 & 832 & 116 & S44 & 8.1 & 700 & 112 & S69 & 7.5 & 480 & 108 & S94 & 7.74 & 383 & 100 \\
\hline S20 & 8.2 & 738 & 120 & S45 & 8.2 & 698 & 120 & $\mathrm{~S} 70$ & 7.5 & 562 & 120 & S95 & 7.77 & 598 & 112 \\
\hline S21 & 7.8 & 740 & 120 & S46 & 8.1 & 694 & 112 & S71 & 7.8 & 286 & 108 & S96 & 7.5 & 689 & 116 \\
\hline S22 & 8.1 & 708 & 108 & S47 & 8 & 656 & 116 & $\mathrm{~S} 72$ & 8 & 359 & 104 & S97 & 7.5 & 685 & 100 \\
\hline S23 & 8.2 & 732 & 120 & S48 & 8.1 & 654 & 108 & S73 & 7.4 & 299 & 112 & S98 & 7.88 & 624 & 116 \\
\hline S24 & 8.3 & 812 & 120 & S49 & 8.2 & 692 & 116 & S74 & 7.2 & 405 & 120 & S99 & 7.72 & 591 & 100 \\
\hline S25 & 8.2 & 800 & 116 & $\mathrm{~S} 50$ & 8 & 694 & 116 & S75 & 7.2 & 405 & 120 & $\mathrm{~S} 100$ & 8.62 & 598 & 112 \\
\hline
\end{tabular}




\begin{tabular}{|c|c|c|c|c|c|c|c|c|c|c|c|c|c|c|c|}
\hline $\begin{array}{l}\text { Sample } \\
\text { Name }\end{array}$ & pH & TDS & Hardness & $\begin{array}{l}\text { Sample } \\
\text { Name }\end{array}$ & pH & TDS & Hardness & $\begin{array}{l}\text { Sample } \\
\text { Name }\end{array}$ & pH & TDS & Hardness & $\begin{array}{l}\text { Sample } \\
\text { Name }\end{array}$ & pH & TDS & Hardness \\
\hline S101 & 7.5 & 683 & 100 & S126 & 8.1 & 618 & 108 & S151 & 7.4 & 612 & 116 & S176 & 8.19 & 744 & 116 \\
\hline S102 & 7.5 & 411 & 100 & S127 & 7.9 & 656 & 120 & $\mathrm{~S} 152$ & 8 & 660 & 120 & S177 & 8.16 & 716 & 120 \\
\hline $\mathrm{S} 103$ & 8.2 & 253 & 100 & $\mathrm{~S} 128$ & 7.6 & 568 & 116 & $\mathrm{~S} 153$ & 8.2 & 764 & 120 & $\mathrm{~S} 178$ & 7.74 & 687 & 116 \\
\hline S104 & 8.0 & 253 & 100 & S129 & 7.9 & 568 & 116 & S154 & 8.2 & 756 & 112 & S179 & 8.13 & 764 & 116 \\
\hline S105 & 7.9 & 273 & 120 & S130 & 7.96 & 982 & 108 & $\mathrm{~S} 155$ & 8.1 & 784 & 112 & $\mathrm{~S} 180$ & 8.16 & 712 & 104 \\
\hline S106 & 8.0 & 247 & 100 & $\mathrm{~S} 131$ & 7.83 & 998 & 110 & S156 & 7.8 & 600 & 104 & $\mathrm{~S} 181$ & 8.16 & 714 & 104 \\
\hline S107 & 7.6 & 591 & 100 & $\mathrm{~S} 132$ & 8 & 604 & 120 & $\mathrm{~S} 157$ & 7.6 & 395 & 118 & $\mathrm{~S} 182$ & 8.12 & 724 & 116 \\
\hline S108 & 7.7 & 591 & 100 & S133 & 7.7 & 582 & 120 & $\mathrm{~S} 158$ & 7.4 & 386 & 116 & $\mathrm{~S} 183$ & 7.86 & 736 & 116 \\
\hline S109 & 8 & 676 & 100 & $\mathrm{~S} 134$ & 8 & 712 & 112 & S159 & 7.9 & 356 & 106 & S184 & 8.12 & 857 & 116 \\
\hline S110 & 7.5 & 570 & 100 & S135 & 7.5 & 586 & 108 & $\mathrm{~S} 160$ & 7.9 & 568 & 108 & $\mathrm{~S} 185$ & 7.93 & 812 & 108 \\
\hline S111 & 7.3 & 481 & 100 & $\mathrm{~S} 136$ & 8.1 & 640 & 120 & $\mathrm{~S} 161$ & 8.1 & 768 & 120 & S186 & 7.72 & 616 & 116 \\
\hline S112 & 7.4 & 507 & 104 & $\mathrm{~S} 137$ & 8.1 & 648 & 112 & $\mathrm{~S} 162$ & 8.2 & 1251 & 100 & $\mathrm{~S} 187$ & 8.12 & 1026 & 108 \\
\hline S113 & 7 & 434 & 120 & S138 & 7.2 & 546 & 116 & S163 & 7.8 & 1173 & 110 & $\mathrm{~S} 188$ & 7.96 & 1064 & 116 \\
\hline S114 & 7.5 & 493 & 100 & S139 & 8.1 & 684 & 116 & S164 & 7.8 & 1016 & 116 & S189 & 7.86 & 1076 & 116 \\
\hline S115 & 7.5 & 390 & 120 & $\mathrm{~S} 140$ & 8 & 608 & 120 & S165 & 7.8 & 746 & 112 & S190 & 8.12 & 964 & 116 \\
\hline S116 & 7.5 & 387 & 100 & S141 & 7.9 & 572 & 120 & S166 & 8.1 & 664 & 116 & $\mathrm{~S} 191$ & 7.78 & 1032 & 116 \\
\hline S117 & 7.5 & 520 & 120 & $\mathrm{~S} 142$ & 8 & 632 & 116 & S167 & 8.1 & 716 & 120 & S192 & 8.24 & 808 & 116 \\
\hline S118 & 7.7 & 409 & 120 & $\mathrm{~S} 143$ & 8 & 688 & 112 & $\mathrm{~S} 168$ & 8.1 & 708 & 116 & S193 & 8.24 & 764 & 116 \\
\hline S119 & 7.5 & 397 & 120 & $\mathrm{~S} 144$ & 8.2 & 658 & 112 & S169 & 8.2 & 640 & 108 & S194 & 8.14 & 856 & 116 \\
\hline S120 & 8 & 606 & 100 & S145 & 8 & 588 & 120 & $\mathrm{~S} 170$ & 8.1 & 984 & 120 & $\mathrm{~S} 195$ & 8.29 & 1230 & 120 \\
\hline $\mathrm{S} 121$ & 7.5 & 519 & 100 & $\mathrm{~S} 146$ & 7.9 & 574 & 112 & $\mathrm{~S} 171$ & 8.4 & 927 & 100 & $\mathrm{~S} 196$ & 8.12 & 638 & 108 \\
\hline $\mathrm{S} 122$ & 8 & 538 & 120 & $\mathrm{~S} 147$ & 8.2 & 726 & 112 & $\mathrm{~S} 172$ & 7.8 & 974 & 116 & S197 & 7.96 & 732 & 104 \\
\hline S123 & 8.2 & 632 & 120 & S148 & 8 & 596 & 112 & S173 & 7.9 & 736 & 120 & S198 & 8.13 & 628 & 104 \\
\hline $\mathrm{S} 124$ & 8.2 & 812 & 116 & S149 & 7.6 & 756 & 112 & $\mathrm{~S} 174$ & 7.9 & 824 & 116 & S199 & 7.92 & 649 & 112 \\
\hline $\mathrm{S} 125$ & 7.7 & 546 & 112 & $\mathrm{~S} 150$ & 7.8 & 626 & 126 & S175 & 7.9 & 684 & 120 & $\mathrm{~S} 200$ & 7.78 & 671 & 120 \\
\hline
\end{tabular}




\begin{tabular}{|c|c|c|c|c|c|c|c|}
\hline $\begin{array}{l}\text { Sample } \\
\text { Name }\end{array}$ & pH & TDS & Hardness & $\begin{array}{l}\text { Sample } \\
\text { Name }\end{array}$ & pH & TDS & Hardness \\
\hline S201 & 7.84 & 652 & 104 & S226 & 6.9 & 273 & 108 \\
\hline S202 & 7.36 & 648 & 104 & S227 & 6.8 & 286 & 112 \\
\hline S203 & 7.98 & 862 & 104 & S228 & 6.9 & 312 & 120 \\
\hline S204 & 8.12 & 893 & 116 & S229 & 7.4 & 276 & 108 \\
\hline S205 & 7.86 & 748 & 116 & $\mathrm{~S} 230$ & 7.2 & 550 & 104 \\
\hline S206 & 7.79 & 718 & 100 & $\mathrm{~S} 231$ & 8.12 & 523 & 116 \\
\hline S207 & 7.5 & 501 & 120 & $\mathrm{~S} 232$ & 8.03 & 313 & 108 \\
\hline S208 & 7.53 & 598 & 100 & $\mathrm{~S} 233$ & 8.21 & 268 & 106 \\
\hline S209 & 7.5 & 512 & 120 & S234 & 7.79 & 309 & 110 \\
\hline S210 & 7.78 & 820 & 120 & $\mathrm{~S} 235$ & 8.18 & 285 & 100 \\
\hline S211 & 7.16 & 741 & 120 & & & & \\
\hline S212 & 7.86 & 742 & 116 & & & & \\
\hline S213 & 7.84 & 720 & 116 & & & & \\
\hline S214 & 7.71 & 824 & 120 & & & & \\
\hline S215 & 7.96 & 724 & 116 & & & & \\
\hline S216 & 7.83 & 820 & 116 & & & & \\
\hline S217 & 8.1 & 840 & 120 & & & & \\
\hline S218 & 7.96 & 960 & 120 & & & & \\
\hline S219 & 7.51 & 960 & 120 & & & & \\
\hline S220 & 8.3 & 806 & 120 & & & & \\
\hline S221 & 8.01 & 720 & 110 & & & & \\
\hline S222 & 6.9 & 403 & 112 & & & & \\
\hline S223 & 6.9 & 312 & 116 & & & & \\
\hline S224 & 6.8 & 276 & 108 & & & & \\
\hline $\mathrm{S} 225$ & 6.9 & 270 & 108 & & & & \\
\hline
\end{tabular}


Table 12S: Physical properties of collected river water samples across the Western Bengal basin

\begin{tabular}{lrrr}
\hline Sample Name & pH & TDS & Hardness \\
\hline WBB1 & 7.72 & 424 & 120 \\
WBB2 & 7.96 & 399 & 120 \\
WBB3 & 7.84 & 373 & 116 \\
WBB4 & 7.84 & 688 & 112 \\
WBB5 & 8.39 & 435 & 110 \\
WBB6 & 7.83 & 576 & 112 \\
WBB7 & 7.99 & 545 & 108 \\
WBB8 & 8.14 & 419 & 110 \\
WBB9 & 7.92 & 456 & 120 \\
WBB10 & 7.92 & 478 & 116 \\
WBB11 & 7.86 & 496 & 108 \\
WBB12 & 8.04 & 420 & 120 \\
WBB13 & 7.93 & 471 & 120 \\
WBB14 & 8.26 & 642 & 100 \\
WBB15 & 7.96 & 685 & 120 \\
WBB16 & 8.25 & 262 & 110 \\
WBB17 & 8.21 & 408 & 100 \\
WBB18 & 8.22 & 235 & 116 \\
WBB19 & 7.71 & 651 & 120 \\
WBB20 & 8.16 & 658 & 120 \\
WBB21 & 8.18 & 436 & 116 \\
WBB22 & 7.96 & 612 & 116 \\
WBB23 & 8.12 & 367 & 108 \\
WBB24 & 7.81 & 274 & 120 \\
WBB25 & 8.25 & 344 & 110 \\
WBB26 & 8.02 & 527 & 110 \\
WBB27 & 7.8 & 262 & 120 \\
WBB28 & 7.8 & 438 & 120 \\
WBB29 & 8 & 404 & 100 \\
WBB30 & 7.5 & 357 & 106 \\
WBB31 & 8.1 & 469 & 120 \\
WBB32 & 7.9 & 500 & 112 \\
\hline & & &
\end{tabular}

